\title{
Quantifying body water kinetics and fecal and urinary water output from lactating Holstein dairy cows
}

\author{
J. A. D. R. N. Appuhamy, ${ }^{* 1}$ C. Wagner-Riddle,† D. P. Casper,‡ J. France,§ and E. Kebreab* \\ *Department of Animal Science, University of California, Davis 95616 \\ †School of Environmental Sciences, University of Guelph, Guelph, ON, N1G 2W1, Canada \\ ‡Department of Dairy Science, South Dakota State University, Brookings 57007 \\ §Centre for Nutrition Modelling, Department of Animal and Poultry Science, University of Guelph, Guelph, ON, N1G 2W1, Canada
}

\begin{abstract}
Reliable estimates of fresh manure water output from dairy cows help to improve storage design, enhance efficiency of land application, quantify the water footprint, and predict nutrient transformations during manure storage. The objective of the study was to construct a mechanistic, dynamic, and deterministic mathematical model to quantify urinary and fecal water outputs $(\mathrm{kg} / \mathrm{d})$ from individual lactating dairy cows. The model contained 4 body water pools: reticulorumen $\left(Q_{R R}\right)$, post-reticulorumen $\left(Q_{P R}\right)$, extracellular $\left(Q_{E C}\right)$, and intracellular $\left(Q_{I C}\right)$. Dry matter $(\mathrm{DM})$ intake, dietary forage, DM, crude protein, acid detergent fiber and ash contents, milk yield, and milk fat and protein contents, days in milk, and body weight were input variables to the model. A set of linear equations was constructed to determine drinking, feed, and saliva water inputs to $Q_{R R}$ and fractional water passage from $Q_{R R}$ to $Q_{P R}$. Water transfer via the rumen wall was subjected to changes in $Q_{E C}$ and total water input to $Q_{R R}$. Post-reticulorumen water passage was adjusted for DM intake. Metabolic water production and respiratory cutaneous water losses were estimated with functions of heat production in the model. Water loss in urine was driven by absorbed $\mathrm{N}$ left after being removed via milk. Model parameters were estimated simultaneously using observed fecal and urinary water output data from lactating Holstein cows $(\mathrm{n}=670)$. The model was evaluated with data that were not used for model development and optimization $(\mathrm{n}=377)$. The observations in both data sets were related to thermoneutral conditions. The model predicted drinking water intake, fecal, urinary, and total fresh manure water output with root mean square prediction errors as a percentage of average values of 18.1, 15.6, 30.6 , and $14.6 \%$, respectively. In all cases, $>97 \%$ of the prediction error was due to random variability of data. The model can also be used to determine saliva produc-
\end{abstract}

Received November 22, 2013.

Accepted June 16, 2014.

${ }^{1}$ Corresponding author: jaappuhamy@ucdavis.edu tion, heat and metabolic water production, respiratory cutaneous water losses, and size of major body water pools in lactating Holstein cows under thermoneutral conditions.

Key words: dairy cow, manure water, mechanistic model, water intake

\section{INTRODUCTION}

In recent years, manure from dairy farms has been identified by regulatory agencies as having a potentially negative effect on air and water quality (Van Horn et al., 1994). Adequate manure storage is needed for convenience and for efficient nutrient recycling and prevention of pollution (Wilkerson et al., 1997). Water in animal excreta and wash water predominantly determine total manure volume, which is a critical factor in designing storage facilities. Moreover, fresh manure volume and composition directly affect chemical reactions releasing nutrients into the environment. For example, volume of urine produced and urea concentration in urine are major determinants of ammonia and nitrous oxide emissions from dairy farms (Bannink et al., 1999; Dijkstra et al., 2013). Manure and soil models, such as the Manure-Denitrification and Decomposition (manure-DNDC) model (Li et al., 2011), mathematically represent postexcretion nutrient dynamics and thereby predict chemical release to the environment. Manure volume and associated nutrient concentrations are vital input variables with these types of models. Moreover, the amount and nutrient concentrations in manure play key roles in land application. For example, with the traditional use of manure as fertilizer, nutrient concentration estimates are important in deciding on storage and transportation requirements and matching crop nutrient needs. Furthermore, water excretion estimates assist in quantifying the water footprint of dairy cows (Mekonnen and Hoekstra, 2012).

Water makes up about $90 \%$ of the urine and feces of lactating Holstein cows (Knowlton et al., 2010; KhelilArfa et al., 2012). Therefore, accuracy of fecal and 
urinary water estimates considerably affects total fresh manure volume estimates. Several empirical models have been proposed to determine urinary (Holter and Urban, 1992; Bannink et al., 1999; Fox et al., 2004; Nennich et al., 2006; Khelil-Arfa et al., 2012) and fecal (Holter and Urban, 1992; Khelil-Arfa et al., 2012) water excretions from lactating dairy cows. The models of Holter and Urban (1992) and Khelil-Arfa et al. (2012) were constructed using an integrated approach that connected water inputs and excretions. Such an approach allows evaluation of water excretion with respect to whole water balance in dairy cows. However, the fecal and urinary water prediction equations in these models were not optimized simultaneously. Therefore, the corresponding parameter estimates may not appropriately represent the real kinetics involved in body water balance. Moreover, the majority of extant empirical equations were constructed using relatively small data sets $(\mathrm{n}<375)$ and several of them were not evaluated with independent data.

A mechanistic model integrates inputs (e.g., drinking water, water in feed) and outputs (e.g., water in milk, urine, and feces) of a system (e.g., lactating dairy cow) while explaining the transition mechanisms (e.g., gut water passage, absorption). Mathematical representation of transient conditions allows for understanding the system dynamics and for estimating important kinetics and key pools sizes, obtaining absolute measurements of which is quite challenging. For example, knowledge of gut and extracellular water volumes is useful in determining their chemical (e.g., nutrient, metabolite) concentrations and is also important in calculating empty BW and thereby body composition (Andrew et al., 1995). However, predictive power and representativeness of a mechanistic model largely depend on appropriateness of the parameterization, which can be considerably enhanced by solving for all model parameters simultaneously by fitting to a large data set. The objectives of the present study were to (1) develop a mechanistic model representing body water balance and related kinetics for determining fecal, urinary, and total fresh manure water output from lactating Holstein cows, (2) optimize the model for all parameters simultaneously using a relatively large data set, and (3) evaluate the model with data not used for model development and optimization.

\section{MATERIALS AND METHODS}

\section{Data Sources}

A total of 1,047 measured fecal or urinary water outputs $(\mathrm{kg} / \mathrm{d})$, and related DMI and drinking water intake (both $\mathrm{kg} / \mathrm{d}$ ), dietary DM percentage and nutrient composition (\% of DM), fecal $\mathrm{N}$ and total ash excretions (both $\mathrm{kg} / \mathrm{d}$ ), milk yield $(\mathrm{kg} / \mathrm{d})$ and composition (\%), BW (kg/cow), and DIM were used for analysis. The measurements were made on 315 lactating Holstein cows from 50 energy balance trials conducted at the former USDA Energy Metabolism Unit (EMU; Beltsville, MD; Wilkerson et al., 1997). Out of a total of 315 cows, 265 cows provided multiple observations ranging from 2 to 24 observations per cow. Data from 33 experiments ( $\mathrm{n}=670$ observations) were randomly assigned for model development, parameter estimation, and internal model evaluation. Data from the rest of the experiments $(\mathrm{n}=377)$ were allocated for external model evaluation. A summary of these 2 data sets is given in Table 1. Additionally, data on rumen liquid volume $(\mathrm{kg})$ and fractional liquid passage rate from the rumen (/d) measured by rumen emptying, time spent eating $\left(\boldsymbol{T}_{\boldsymbol{E} T}\right)$ and ruminating $\left(\boldsymbol{T}_{\boldsymbol{R} M}\right) 1 \mathrm{~kg}$ of DM (min/ $\mathrm{kg})$, and salivary secretion rates $(\mathrm{mL} / \mathrm{min})$ measured during eating, ruminating, and resting were extracted from 51 studies in the published literature on lactating Holstein dairy cows (Table 2). Associated DMI, diet nutrient composition, milk production and composition, BW, and DIM were also extracted. See Table 3 for definitions of mathematical notation and parameter abbreviations used in models.

\section{Model Development}

The model was constructed as a deterministic, dynamic, and mechanistic representation of major body water kinetics (Figure 1) in lactating dairy cows. The time unit for fluxes (Figure 1) and the mass unit for the model were days and kilograms, respectively. The model contained 4 body water pools: reticulorumen water $\left(\boldsymbol{Q}_{\boldsymbol{R}}\right)$; water in the rest of the gut (i.e., post-reticulorumen compartments; $\boldsymbol{Q}_{P R}$ ); extracellular water including that in blood and interstitial fluid $\left(\boldsymbol{Q}_{E C}\right)$; and intracellular water $\left(\boldsymbol{Q}_{I C}\right)$. Water inputs to $Q_{R R}$ were saliva $\left(\boldsymbol{F}_{S l, R R}\right)$, free or drinking water $\left(\boldsymbol{F}_{\boldsymbol{D}, \boldsymbol{R} \boldsymbol{R}}\right)$, and water in feed $\left(\boldsymbol{F}_{\boldsymbol{F d}, \boldsymbol{R} \boldsymbol{R}}\right)$. Although water is exchanged between the gut and $Q_{E C}$ via absorption, resorption, and secretions (Remond et al., 1996), for model parsimony, only the net water flows across the reticulorumen wall and rest of the gut wall $\left(\boldsymbol{F}_{\boldsymbol{R}, \boldsymbol{E} C}\right.$ and $\boldsymbol{F}_{P R, E C}$, respectively, Figure 1) were included. Some water in $Q_{E C}$ flows back to the rumen via $F_{S l, R R}$, and some is used for milk $\left(\boldsymbol{F}_{\boldsymbol{E} C, M l}\right)$, urine $\left(\boldsymbol{F}_{\boldsymbol{E C}, \boldsymbol{U r}}\right)$ and as respiratory-cutaneous losses $\left(\boldsymbol{F}_{\boldsymbol{E} C, \boldsymbol{E v}}\right)$. Water is continuously exchanged between $Q_{E C}$ and $Q_{I C}$ but only a net water transfer from $Q_{I C}$ to $Q_{E C}\left(\boldsymbol{F}_{I C, E C}\right)$ was included in the model (Figure 1). Metabolic water produced within the cells was added into $Q_{I C}\left(\boldsymbol{F}_{M w, I C}\right)$. Although some water can be retained in the body, particularly in early 
Table 1. Summary of data set used in model development, optimization, and internal evaluation (data set 1) and data set used in external model evaluation (data set 2)

\begin{tabular}{|c|c|c|c|c|c|c|}
\hline \multirow[b]{2}{*}{ Variable } & \multicolumn{3}{|c|}{$\mathrm{EMU}^{1}$ data set $1(\mathrm{n}=670)$} & \multicolumn{3}{|c|}{ EMU data set $2(\mathrm{n}=377)$} \\
\hline & Mean & Minimum & Maximum & Mean & Minimum & Maximum \\
\hline Fecal & 25.6 & 6.2 & 46.8 & 25.9 & 7.5 & 45.1 \\
\hline Urinary & 16.3 & 4.2 & 35.8 & 16.1 & 4.7 & 35.8 \\
\hline Total & 41.9 & 15.9 & 80.7 & 41.9 & 18.9 & 75.7 \\
\hline \multicolumn{7}{|l|}{ Water and DMI, kg/d } \\
\hline \multicolumn{7}{|l|}{ Diet composition } \\
\hline Forage percentage & 49 & 15 & 95 & 50 & 0 & 100 \\
\hline DM percentage & 66.1 & 30.2 & 97.4 & 70.3 & 37.3 & 93.3 \\
\hline $\mathrm{CP}, \%$ of $\mathrm{DM}$ & 16.5 & 8.2 & 22.3 & 16.4 & 9.2 & 27.2 \\
\hline $\mathrm{NDF}, \%$ of DM & 33.5 & 14.9 & 76.1 & 33.9 & 14.6 & 71.1 \\
\hline $\mathrm{ADF}, \%$ of $\mathrm{DM}$ & 19.4 & 7.8 & 47.1 & 19.7 & 7.5 & 41.1 \\
\hline Ash, $\%$ of DM & 6.3 & 3.5 & 10.0 & 6.5 & 3.4 & 11.8 \\
\hline DIM & 162 & 11 & 488 & 167 & 0 & 524 \\
\hline $\mathrm{BW}, \mathrm{kg}$ & 603 & 387 & 854 & 593 & 403 & 807 \\
\hline \multicolumn{7}{|l|}{ Other } \\
\hline $\mathrm{N}$ intake, $\mathrm{kg} / \mathrm{d}$ & 0.43 & 0.14 & 0.82 & 0.40 & 0.18 & 0.93 \\
\hline Absorbed $\mathrm{N}\left(N_{A b}\right), \mathrm{kg} / \mathrm{d}$ & 0.26 & 0.06 & 0.58 & 0.27 & 0.11 & 0.45 \\
\hline$N_{A b}-$ milk protein $\mathrm{N}, \mathrm{kg} / \mathrm{d}$ & 0.16 & 0.01 & 0.38 & 0.16 & 0.03 & 0.31 \\
\hline Heat production, ${ }^{2} \mathrm{Mcal} / \mathrm{d}$ & 25.7 & 12.5 & 42.1 & 25.6 & 13.0 & 38.9 \\
\hline
\end{tabular}

${ }^{1}$ Data from indirect calorimetry experiments conducted in the USDA-Energy Metabolism Unit (EMU; Beltsville, MD).

${ }^{2}$ Estimated with the Brouwer (1965) equation.

lactation (Woodford et al., 1984), this was not included in the model because water retained has little effect on body water balance compared with the other fluxes (Silanikove et al., 1997).

Reticulorumen Water Kinetics. The size of $Q_{R R}$ depends on the balance between $F_{S l, R R}, F_{D r, R R}, F_{F d, R R}$, $F_{R R, E C}$, and water passage from the reticulo-rumen to the rest of the gut $\left(\boldsymbol{F}_{\boldsymbol{R} R, \boldsymbol{P}}\right.$, Figure 1). Daily saliva water input was estimated with respect to 3 attributes: eating, ruminating, and resting. Saliva flow in each stage was separately estimated as a product of duration of each stage $(\mathrm{min} / \mathrm{d})$ and saliva secretion rate $(\mathrm{kg} /$ min). Two linear regression equations were developed to estimate $T_{E T}$ and $T_{R M}$ using the data extracted from the literature. Correlations (r) of DMI, dietary forage percentage, dietary DM percentage, dietary $\mathrm{CP}, \mathrm{ADF}$, NDF and total ash contents, milk yield, BW, and DIM with $T_{E T}$ and $T_{R T}$ were separately tested. A full model that included all variables having appreciable correlations $(\mathrm{R}>0.25)$ was first constructed. Reduced models were then formed via stepwise elimination of one variable at a time. The final prediction models were chosen by testing reduced models against full models using loglikelihood ratio tests. Multicollinearity was considered when choosing variables in the models. Highly corre- lated variables (e.g., dietary forage and NDF contents) were not included together. Models were selected based on Bayesian information criteria (BIC) values. Both the final models predicting $T_{E T}$ and $T_{R M}$ (equations [1] and [2] respectively; Table A1 in the Appendix) included DMI and dietary forage percentage. Numbered equations are presented in the Appendix.

Daily eating $\left(\boldsymbol{D}_{\boldsymbol{E} T}\right)$, ruminating $\left(\boldsymbol{D}_{R M}\right)$, and resting $\left(\boldsymbol{D}_{R S}\right)$ durations $(\mathrm{min} / \mathrm{d})$ were calculated using equations [3], [4], and [5], respectively. Saliva secretion rates $(\mathrm{kg} / \mathrm{min})$ during eating $\left(\boldsymbol{S}_{\boldsymbol{E} T}\right)$ and resting $\left(\boldsymbol{S}_{\boldsymbol{R} S}\right)$ were estimated using 2 linear equations (equations [6] and [7], respectively) developed from literature data (Cassida and Stokes, 1986; Maekawa et al., 2002; Beauchemin et al., 2003, 2008; Bowman et al., 2003; Mooney and Allen, 2007). Variables and final equations were selected with the same approach used for the $T_{E T}$ and $T_{R M}$ equations. A constant saliva secretion of $0.23 \mathrm{~kg} /$ min, equal to the average secretion measures reported in the literature (Table 2), was assumed during ruminating $\left(\boldsymbol{S}_{\boldsymbol{R} M}\right)$. Daily saliva production $\left(F_{S l, R R}\right)$ was then calculated with the $D_{E T}, D_{R M}$, and $D_{R S}$ values and corresponding saliva secretion rates (equation [8]).

Drinking water intake was estimated with a linear equation developed using the EMU data allocated 
Table 2. Summary of data collected from the literature ${ }^{1}$

\begin{tabular}{|c|c|c|c|}
\hline Variable & Mean & Minimum & Maximum \\
\hline \multicolumn{4}{|l|}{ Response $^{2}$} \\
\hline$Q_{R R}, \mathrm{~kg}(\mathrm{n}=81)$ & 72.0 & 55.0 & 86.1 \\
\hline$k_{R R, P R} / \mathrm{h}(\mathrm{n}=88)$ & 0.12 & 0.08 & 0.16 \\
\hline$T_{E T}, \min / \mathrm{kg}$ of DMI $(\mathrm{n}=113)$ & 13.3 & 5.0 & 30 \\
\hline$T_{R M}, \min / \mathrm{kg}$ of DMI $(\mathrm{n}=110)$ & 20.8 & 9.5 & 55 \\
\hline$S_{E T}, \mathrm{~kg} / \min (\mathrm{n}=20)$ & 0.21 & 0.17 & 0.25 \\
\hline$S_{R M}, \mathrm{~kg} / \min (\mathrm{n}=7)$ & 0.23 & 0.21 & 0.25 \\
\hline$S_{R S}, \mathrm{~kg} / \min (\mathrm{n}=10)$ & 0.12 & 0.09 & 0.16 \\
\hline \multicolumn{4}{|l|}{ DMI and diet composition } \\
\hline DMI $(\mathrm{kg} / \mathrm{d}, \mathrm{n}=229)$ & 22.2 & 13.9 & 31.6 \\
\hline Forage percentage $(\mathrm{n}=214)$ & 52.5 & 16.0 & 100 \\
\hline DM percentage $(\mathrm{n}=194)$ & 55.8 & 15.0 & 90.5 \\
\hline $\mathrm{CP}, \%$ of $\mathrm{DM}(\mathrm{n}=210)$ & 16.5 & 14.5 & 24.7 \\
\hline $\mathrm{NDF}, \%$ of DM $(\mathrm{n}=211)$ & 33.3 & 24.5 & 80.0 \\
\hline $\mathrm{ADF}, \%$ of $\mathrm{DM}(\mathrm{n}=173)$ & 19.7 & 12.5 & 49.0 \\
\hline Ash, $\%$ of DM $(n=207)$ & 7.4 & 5.0 & 12.8 \\
\hline \multicolumn{4}{|l|}{ Production and other characteristics } \\
\hline Milk yield, kg/d $(\mathrm{n}=210)$ & 32.6 & 20.0 & 49.3 \\
\hline Milk protein, \% $(\mathrm{n}=210)$ & 3.1 & 2.6 & 3.8 \\
\hline DIM $(\mathrm{n}=210)$ & 101 & 7 & 300 \\
\hline $\mathrm{BW}, \mathrm{kg} / \mathrm{cow}(\mathrm{n}=117)$ & 639 & 523 & 886 \\
\hline
\end{tabular}

${ }^{1}$ Agle et al., 2010; Alamouti et al., 2009; Beauchemin et al., 2008; Beauchemin and Yang, 2005; Beauchemin et al., 2003; Bowman et al., 2002, 2003; Canale et al., 1988; Casper et al., 1999; Cassida and Stokes, 1986; Couderc et al., 2006; Dado and Allen, 1995; Fernandez et al., 2004; Kammes and Allen, 2012; Kammes et al., 2012a,b; Kargar et al., 2010; Kendall et al., 2009; Kononoff and Heinrichs, 2003a,b; Kononoff et al., 2003; Krämer et al., 2013; Krause et al., 2003; Le Liboux and Peyraud, 1998; Lechartier and Peyraud, 2010, 2011; Lykos et al., 1997; Maekawa et al., 2002; Mathew et al., 2011; Maulfair and Heinrichs, 2013a,b; Maulfair et al., 2010; Mooney and Allen, 2007; Mowrey et al., 1999; Noftsger et al., 2005; Oba and Allen, 2000; Rabelo et al., 2001; Reis and Combs, 2000a,b; Rius et al., 2012; Sairanen et al., 2005; San Emeterio et al., 2000; Soltani et al., 2009; Stensig and Robinson, 1997; Storm and Kristensen, 2010; Teimouri Yansari et al., 2004; Woodford and Murphy, 1988; Yang and Beauchemin, 2006a,b; Yang et al., 2001; Zebeli et al., 2007.

${ }^{2} Q_{R R}=$ reticulorumen water pool size (from rumen evacuation), $k_{R R, P R}=$ fractional rate of water passage from rumen, $T_{E T}=$ eating time, $T_{R M}=$ ruminating time, $S_{E T}=$ saliva secretion rate during eating, $S_{R M}=$ saliva secretion rate during ruminating, $S_{R S}=$ saliva secretion rate during resting.

for model development. Variables and final equation were selected as described above. The final equation included positive and independent effects of DMI, milk yield, and dietary total ash and DM percentages (equation [9]). Moreover, the equation was evaluated using data not used in its construction and compared with 3 extant equations for predicting drinking water intake in lactating dairy cows (Murphy et al., 1983; Holter and Urban, 1992; Khelil-Arfa et al., 2012). The equation developed here performed better than the extant ones; therefore, it was included in our model to estimate $F_{D r, R R}$. Some drinking water is passed directly to the abomasum via the esophageal groove in cattle (Woodford et al., 1984). Two studies (Woodford et al., 1984; Cafe and Poppi, 1994) provided 4 estimates (treatment means) for fractions of drinking water bypassing the rumen in cattle. An average of these 4 estimates (0.17) was used to represent drinking water entering rumen $\left(F_{D r, R R}\right.$, equation [10]). Water entering $Q_{R R}$ with feed $\left(F_{F d, R R}\right)$ was calculated using DMI and dietary DM percentage (equation [11]).
A mass action equation [15] was used to compute $F_{R R, E C}$, which depends primarily on the osmotic pressure gradient between rumen contents and blood (Warner and Stacy, 1972). Silanikove and Tadmore (1989) showed a significantly high $F_{R R, E C}$ in response to increased blood plasma osmolality in dehydrated cattle, where the $Q_{E C}$ to $\mathrm{BW}$ ratio $(\boldsymbol{E} \boldsymbol{C B} \boldsymbol{W}$, equation [12]) decreased below 0.10 . Accordingly, the basal fractional rate $\left(k_{R R, E C}^{*}\right)$ was adjusted for changes in $E C B W$ relative to a reference $E C B W\left(\boldsymbol{R}_{E C B W}\right)$ in determining the fractional rate of net water passage across the reticulorumen wall $\left(\boldsymbol{k}_{R R, E C}\right)$. A sensitivity exponent $\left(\boldsymbol{n}_{E C B W}\right)$ was used to represent accurately the responsiveness of $F_{R R, E C}$ to this adjustment. Moreover, $k_{R R, E C}^{*}$ was additionally adjusted for total water flow $\left(\boldsymbol{T}_{R R W a t e r}\right.$, equation [13]) relative to a reference flow $\left(\boldsymbol{R}_{R R \text { Water }}\right)$ as for $E C B W$ (equation [14]). This adjustment represents the potential osmolality decrease in reticulorumen fluid, which in turn enhances net water transfer via the rumen wall (Anil et al., 1993; Storm et al., 2012). The adjusted fractional rate of the net water transfer 
Table 3. Mathematical notation

\begin{tabular}{|c|c|}
\hline Symbol & Description \\
\hline \multicolumn{2}{|l|}{ Pools (kg) } \\
\hline$Q_{R R}$ & Reticulorumen \\
\hline$Q_{P R}$ & Post-reticulorumen \\
\hline$Q_{E C}$ & Extracellular \\
\hline$Q_{I C}$ & Intracellular \\
\hline \multicolumn{2}{|c|}{ Flows $(\mathrm{kg} / \mathrm{d})$} \\
\hline$F_{S l, R R}$ & Saliva to $Q_{R R}$ \\
\hline$F_{D r, R R}$ & Drinking water to $Q_{R R}$ \\
\hline$F_{D r, P R}$ & Drinking water bypassing the reticulorumen and reaching $Q_{P R}$ \\
\hline$F_{F d, R R}$ & Water in feed to $Q_{R R}$ \\
\hline$F_{R R, E C}$ & Net water flow from $Q_{R R}$ to $Q_{E C}$ through reticulorumen wall \\
\hline$F_{R R, P R}$ & Passage from $Q_{R R}$ to $Q_{P R}$ \\
\hline$F_{P R, E C}$ & Net water flow from $Q_{P R}$ to $Q_{E C}$ through post-reticulorumen wall \\
\hline$F_{I C, E C}$ & Net water from $Q_{I C}$ to $Q_{E C}$ \\
\hline$F_{P R, F c}$ & Fecal water excretion \\
\hline$F_{E C, M l}$ & Water in milk \\
\hline$F_{E C, E v}$ & Respiratory and cutaneous water (RCW) loss \\
\hline$F_{E C, U r}$ & Urinary water excretion \\
\hline$F_{M w, I C}$ & Metabolic water to $Q_{I C}$ \\
\hline \multicolumn{2}{|c|}{ Model input variables } \\
\hline Forage\% & Percentage of forage in the diet \\
\hline$D M I$ & DMI $(\mathrm{kg} / \mathrm{d})$ \\
\hline Milk & Milk yield (kg/d) \\
\hline Ash & Dietary ash content ( $\%$ of $\mathrm{DM})$ \\
\hline$C P$ & Dietary $\mathrm{CP}$ content $(\% \mathrm{DM})$ \\
\hline$D M$ & Dietary DM percentage \\
\hline$A D F$ & Dietary ADF content (\% of DM) \\
\hline MilkP & Milk true protein percentage \\
\hline MilkF & Milk fat percentage \\
\hline$B W$ & $\mathrm{BW}(\mathrm{kg} / \mathrm{cow})$ \\
\hline$D I M$ & DIM \\
\hline \multicolumn{2}{|l|}{ Other } \\
\hline$T_{E T}$ & Time spent eating $1 \mathrm{~kg}$ of DMI $(\mathrm{min} / \mathrm{kg})$ \\
\hline$T_{R M}$ & Time spent ruminating $1 \mathrm{~kg}$ of $\mathrm{DMI}(\mathrm{min} / \mathrm{kg})$ \\
\hline$D_{E T}$ & Eating duration $(\mathrm{min} / \mathrm{d})$ \\
\hline$D_{R M}$ & Ruminating duration $(\mathrm{min} / \mathrm{d})$ \\
\hline$D_{R S}$ & Resting duration $(\mathrm{min} / \mathrm{d})$ \\
\hline$S_{E T}$ & Saliva secretion rate during eating $(\mathrm{kg} / \mathrm{min})$ \\
\hline$S_{R M}$ & Saliva secretion rate during ruminating $(\mathrm{kg} / \mathrm{min})$ \\
\hline$S_{R S}$ & Saliva secretion rate during resting $(\mathrm{kg} / \mathrm{min})$ \\
\hline$k_{R R, P R}$ & Fractional rate of water passage from $Q_{R R}$ to $Q_{P R}(/ \mathrm{d})$ \\
\hline$E C B W$ & Ratio of $Q_{E C}: B W$ \\
\hline$T_{R R \text { Water }}$ & Total water entering $Q_{R R}(\mathrm{~kg} / \mathrm{d})$ \\
\hline$N_{A b}$ & Absorbed total $\mathrm{N}(\mathrm{kg} / \mathrm{d})$ \\
\hline$N_{B}$ & Absorbed total $\mathrm{N}$ remaining in the body after removal via milk $(\mathrm{kg} / \mathrm{d})$ \\
\hline$H P$ & Heat production $(\mathrm{MCal} / \mathrm{d})$ \\
\hline
\end{tabular}

$\left(\boldsymbol{k}_{R \boldsymbol{R}, \boldsymbol{E C}}\right)$ was then used in the mass action equation (equation [15]) to calculate $F_{R R, E C}$.

A linear regression equation was constructed to determine fractional water passage from $Q_{R R}$ to $Q_{P R}$ $\left(k_{R R, P R}\right)$ using the literature data (Table 2). When the random variability between studies was accounted for, the equation included only independent and positive effects of DMI and dietary ADF content (equation [16]). The estimated $k_{R R, P R}$ was then used in a mass action equation to determine $F_{R R, P R}$ (equation [17]). The rate at which $Q_{R R}$ changes $(\mathrm{kg} / \mathrm{d})$ was calculated using an ordinary differential equation (equation [18]), representing balance between water inflows to and outflows from $Q_{R R}$ (Figure 1).
Water Kinetics After Reticulorumen. Water passage from $Q_{R R}\left(\boldsymbol{F}_{\boldsymbol{R} \boldsymbol{R}, \boldsymbol{P} \boldsymbol{R}}\right)$ and drinking water bypassing the reticulorumen $\left(\boldsymbol{F}_{D r, P R}\right.$, equation [19]) were inputs to $Q_{P R}$, whereas net water transfer to blood through the hindgut wall $\left(\boldsymbol{F}_{\boldsymbol{P R}, \boldsymbol{E} C}\right)$ and fecal water output $\left(\boldsymbol{F}_{\boldsymbol{P R}, \boldsymbol{F c}}\right)$ were the major outputs (Figure 1). Fractional rate of water passage via the hind gut wall was initially adjusted for $E C B W$ as in reticulorumen compartment. However, a sensitivity analysis showed that fecal and urinary excretions were minimally responsive to such adjustment. Therefore, a constant fractional rate $\left(\boldsymbol{k}_{P R, E C}\right)$ was used in a mass action equation (equation [20]) to estimate $F_{P R, E C}$. Dry matter intake has been found to be positively associated with 


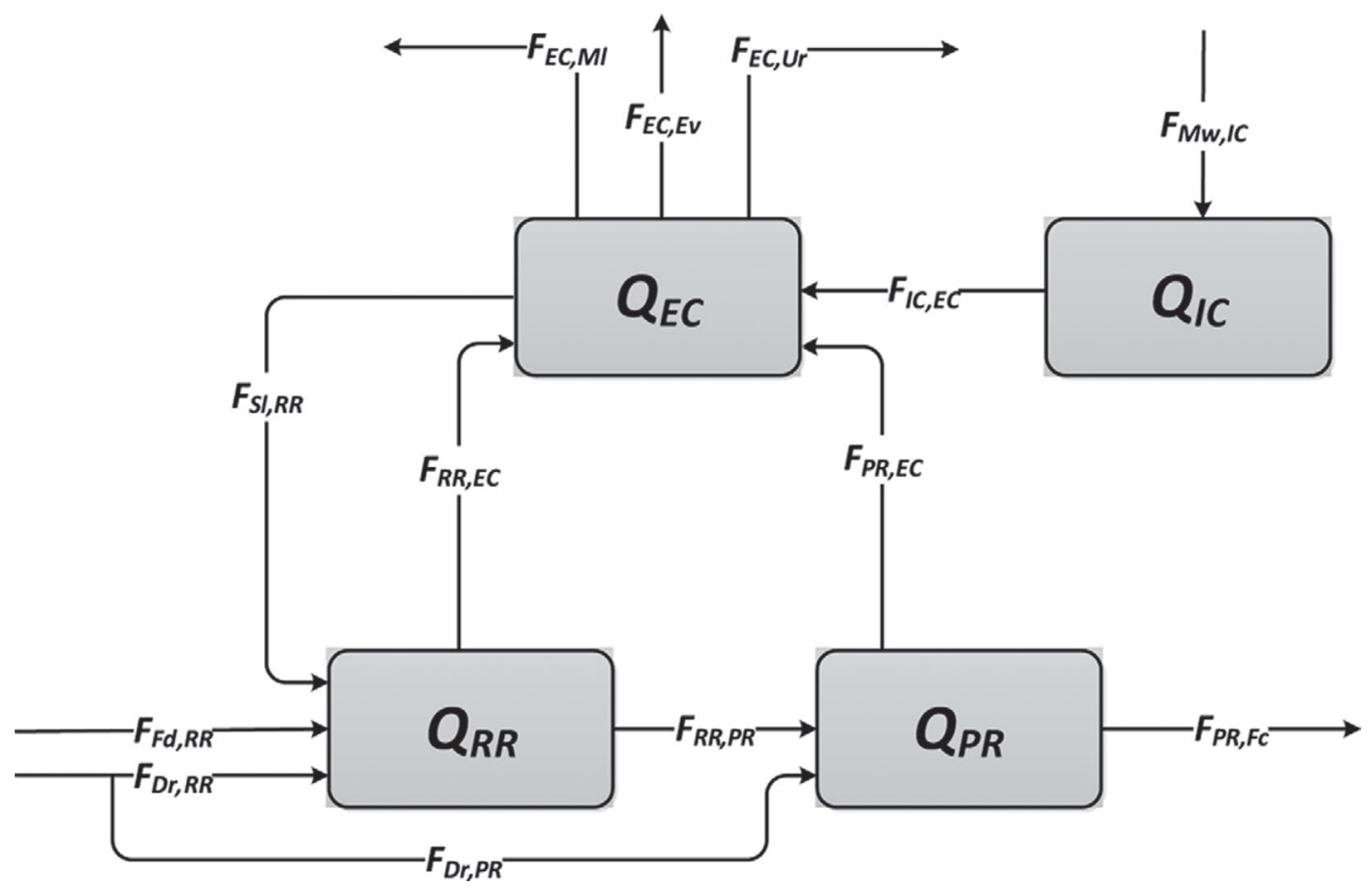

Figure 1. Schematic representation of water kinetics in the model. The boxes and arrows represent pools $(Q)$ and flows $(F)$, respectively. $Q_{R R}=$ reticulorumen pool; $Q_{P R}=$ post-reticulorumen pool; $Q_{E C}=$ extracellular pool; $Q_{I C}=$ intracellular pool; $F_{S l, R R}=$ saliva to $Q_{R R} ; F_{D r, R R}$ $=$ drinking water to $Q_{R R} ; F_{D r, P R}=$ drinking water bypassing the reticulorumen and reaching $Q_{P R} ; F_{F d, R R}=$ water in feed to $Q_{R R} ; F_{R R, E C}=$ net water flow from $Q_{R R}$ to $Q_{E C}$ through reticulorumen wall; $F_{R R, P R}=$ passage from $Q_{R R}$ to $Q_{P R} ; F_{P R . E C}=$ net water flow from $Q_{P R}$ to $Q_{E C}$ through post-reticulorumen wall; $F_{I C, E C}=$ net water from $Q_{I C}$ to $Q_{E C} ; F_{P R, F C}=$ fecal water excretion; $F_{E C, M l}=$ water in milk; $F_{E C, E v}=$ respiratory and cutaneous water $(\mathrm{RCW})$ loss; $F_{E C, U r}=$ urinary water excretion; $F_{M w, I C}=$ metabolic water to $Q_{I C}$.

fractional water passage rates in both the foregut and hindgut in cattle (Huhtanen and Kukkonen, 1995). Assuming independent DMI effects in fore and hindgut, a basal fractional rate $\left(k_{P R, F c}^{*}\right)$ was adjusted for the positive effect of DMI (equation [21]) in determining the final fractional rate $\left(\boldsymbol{k}_{P R, F c}\right)$, which was then used to estimate $F_{P R, F c}$ (equation [22]). The rate at which $Q_{P R}$ changes was determined using an ordinary differential equation (equation [23]).

Extracellular Water Kinetics. Besides that used for saliva production, a considerable amount of water from $Q_{E C}$ is secreted in milk. Water in milk $\left(F_{E C, M l}\right)$ was calculated (equation [24]) assuming that milk has a fixed water content of $87 \%$ (Winchester and Morris, 1956). Absorbed N ( $\boldsymbol{N}_{\boldsymbol{A} b}$, equation [25]) that was available for excretion in urine $\left(\boldsymbol{N}_{\boldsymbol{B}}\right)$ was chosen to drive urine volume and was calculated by subtracting milk protein $\mathrm{N}$ from $N_{A b}$ (equation [26]). Equation [25] was constructed to estimate $N_{A b}$ using EMU data (Table 1). As absolute regulatory mechanisms of body water homeostasis potentially cause nonlinear relationships (Bannink et al., 1999), the Michaelis-Menten equation (Michaelis and Menten, 1913) and the Hill equation (Hill, 1910) were chosen and separately tested for representing the relationship between $N_{B}$ and urine volume.
The Hill equation performed better, so it was included in the final model. Representation of the relationship between $N_{B}$ and $F_{E C, U r}$ was improved with an intercept adjustment ( $a$ in equation [27]) to the Hill equation.

In modeling the fractional rate of respiratory-cutaneous water $(\mathbf{R C W})$ losses $\left(\boldsymbol{k}_{E C, E v}\right)$, a basal fractional rate $\left(k_{E C, E v}^{*}\right)$ was adjusted for positive effect of heat production $(\boldsymbol{H P})$ that changes relative to a reference $H P\left(\boldsymbol{R}_{H P}\right.$, equation [29]). Moreover, $k_{E C, E v}$ was modeled to increase from a minimum rate $\left(\boldsymbol{k}_{E C, E \boldsymbol{v}(\min )}\right.$, equation [29]). A linear equation was developed using EMU data for estimating $H P$ within the model. The final equation included only positive effects of DMI, milk protein percentage, and BW, and negative effects of dietary DM percentage, DIM, and milk fat percentage (equation [28]). As described before, variable and model selections were conducted taking into account the random study and animal effects. The $k_{E C, E v}$ was then used in a mass action equation to calculate $F_{E C, E v}$ (equation [30]). The rate at which $Q_{E C}$ changes was determined using an ordinary differential equation (equation [31]).

Intracellular Water Kinetics. Net water transfer from $Q_{I C}$ to $Q_{E C}\left(\boldsymbol{F}_{I C, E C}\right)$ was represented with a mass action equation (equation [32]). Metabolic water $\left(\boldsymbol{F}_{M w, I C}\right)$ produced from combustion of carbohydrate, 
protein, and fat was represented using a linear function of HP (equation [33]) derived by Morrison (1953). The rate at which $Q_{I C}$ changes with time was determined using an ordinary differential equation [34].

\section{Model Simulation, Optimization, and Sensitivity Analysis}

Input variables to the model were DMI, dietary forage percentage, dietary $\mathrm{DM}, \mathrm{CP}$, ash, and $\mathrm{ADF}$ contents (\% of DM), milk yield, milk protein and fat percentages, DIM, and BW. The model, having drinking water intake, $F_{S l, R R}, k_{R R, P R}, N_{B}$, and $H P$ estimated within it, was run iteratively (interval $=0.5 \mathrm{~d}$ ) until the body water pools reached steady state. The simulations used parameter values that were calculated or determined iteratively using the EMU and literature data. Sizes of the body water pools $\left(Q_{R R}, Q_{P R}, Q_{E C}\right.$, and $\left.Q_{I C}\right)$ were calculated by numerical integration of the corresponding differential equations ([18], [23], [31], [34]) using a Runge-Kutta fourth-order integration method with an integration step size of $0.5 \mathrm{~d}$. The body water pool sizes, and thereby the excretion fluxes achieved
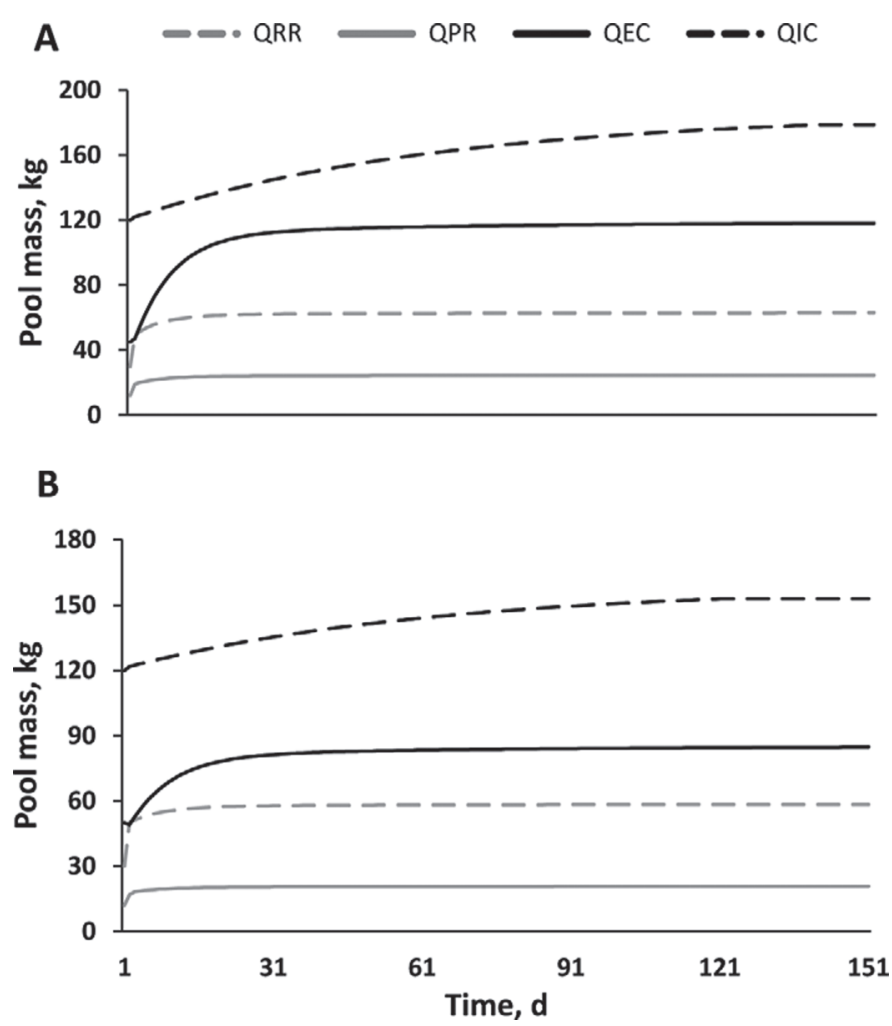

Figure 2. Simulated average pool sizes $(\mathrm{QRR}=$ reticulorumen, $\mathrm{QPR}=$ rest of the gut after reticulorumen, $\mathrm{QEC}=$ extracellular, and QIC = intracellular) changing over time for cows eating high-forage diets (A, forage content $>70 \%$ of the diet) and low-forage diets (B, forage content $<30 \%$ of the diet). steady state within $150 \mathrm{~d}$, when simulated for different input variables (e.g., high forage diets vs. low forage diets, Figure 2). The steady-state values correspond to predicted body pool sizes and fecal and urinary water excretions. Observed values of urine and fecal water output (Table 1) from the EMU database were then set at $150 \mathrm{~d}$. The EMU experiments provided total urine weights. Thus, the observed urinary water output values were calculated assuming that water made up $95 \%$ of total urine weight (ASAE, 2005). The model was fitted against these observed values and solved simultaneously for all the model parameters in question (Table 4) using a generalized-nonlinear least square search algorithm (Dennis et al., 1981). The parameter estimates were then used to conduct sensitivity analysis to quantify the sensitivity of fecal, urinary, and total water excretion predictions at steady state to the model parameters. Sensitivity of all parameters were analyzed simultaneously; therefore, the resulting coefficients $(\boldsymbol{S})$ were partial derivatives describing independent sensitivities of fecal and urinary excretion responses to each model parameter (McPhee et al., 2009). Sensitivity coefficients were normalized to both parameter values and response values. Such normalization allows for comparisons of $S$ not only across parameters but also across responses (e.g., $S$ of urinary water vs. fecal water, Table 5).

\section{Model Evaluation}

The model was internally (with the data used for model development) and externally (with data not used for development) evaluated for fecal and urinary water excretions. Additionally, the model predictions of $Q_{R R}$ were compared with measured values (by rumen evacuation) reported in the literature $(\mathrm{n}=81)$. Linear and residual analyses were conducted for model evaluation. Additional model adequacy statistics were calculated to understand sources of prediction error. Square root of mean square prediction error (RMSPE) is directly comparable to observed values so that RMSPE was calculated and expressed as a percentage of the average observed value of the response variable. Mean square prediction error was decomposed to central tendency (mean bias), regression (slope bias), and nonsystematic or random variability of data to give relative estimates of sources of error (Bibby and Toutenburg, 1977). Model development, simulations, and evaluations were carried out using the FME and lme 4 packages in $\mathrm{R}$ (version 2.12.2, R Foundation for Statistical Computing, Vienna, Austria). Model optimization and sensitivity analyses were carried out using acslXtreme software (AEgis Technologies, Huntsville, AL). 
Table 4. Notation of parameters for which the model was optimized ${ }^{1}$

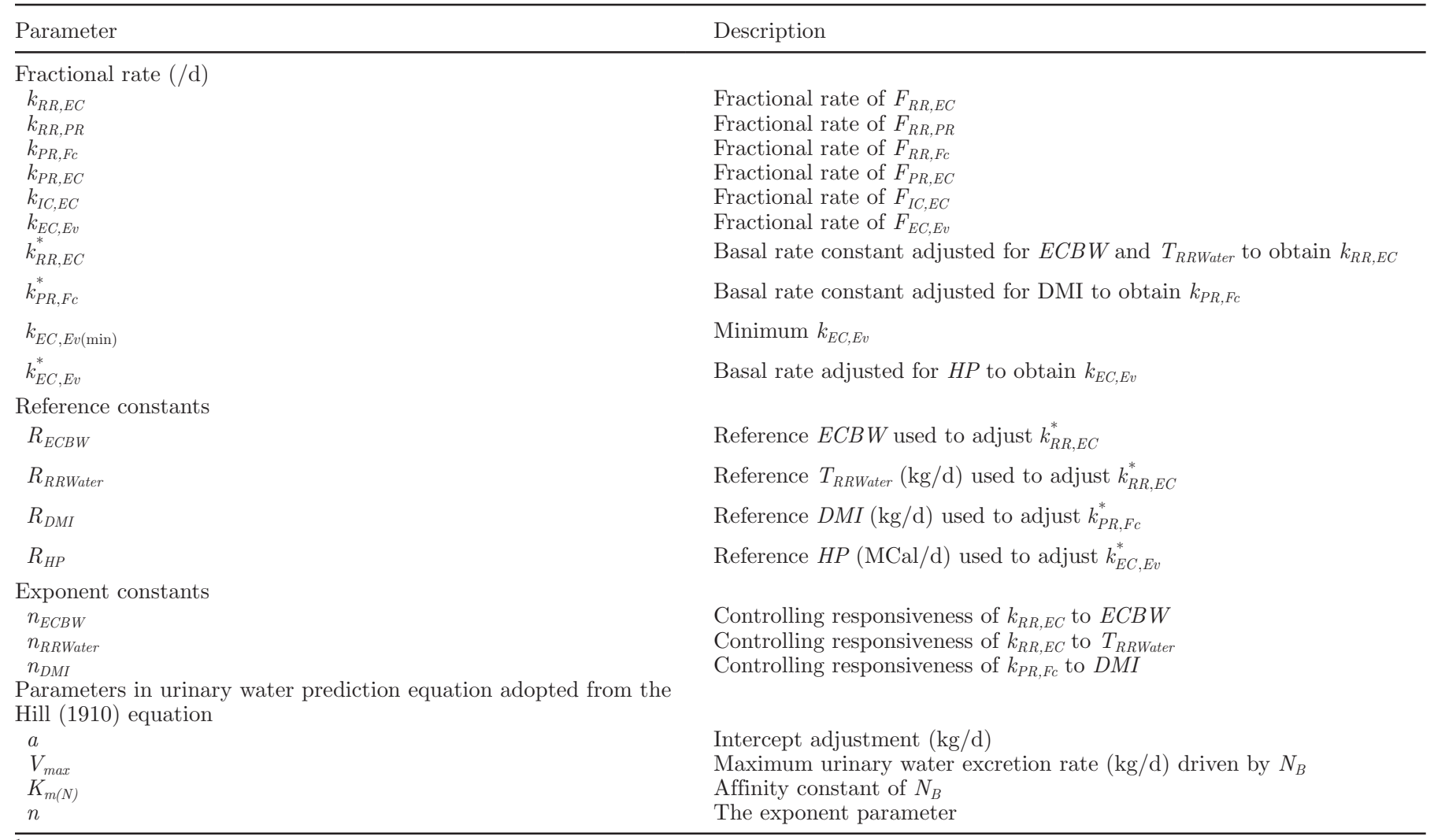

${ }^{1}$ See Table 3 for definition of mathematical notation and parameter abbreviations used in models.

Table 5. Model parameter estimates and sensitivity coefficients $(S)$ for fecal, urinary, and total manure water output predictions

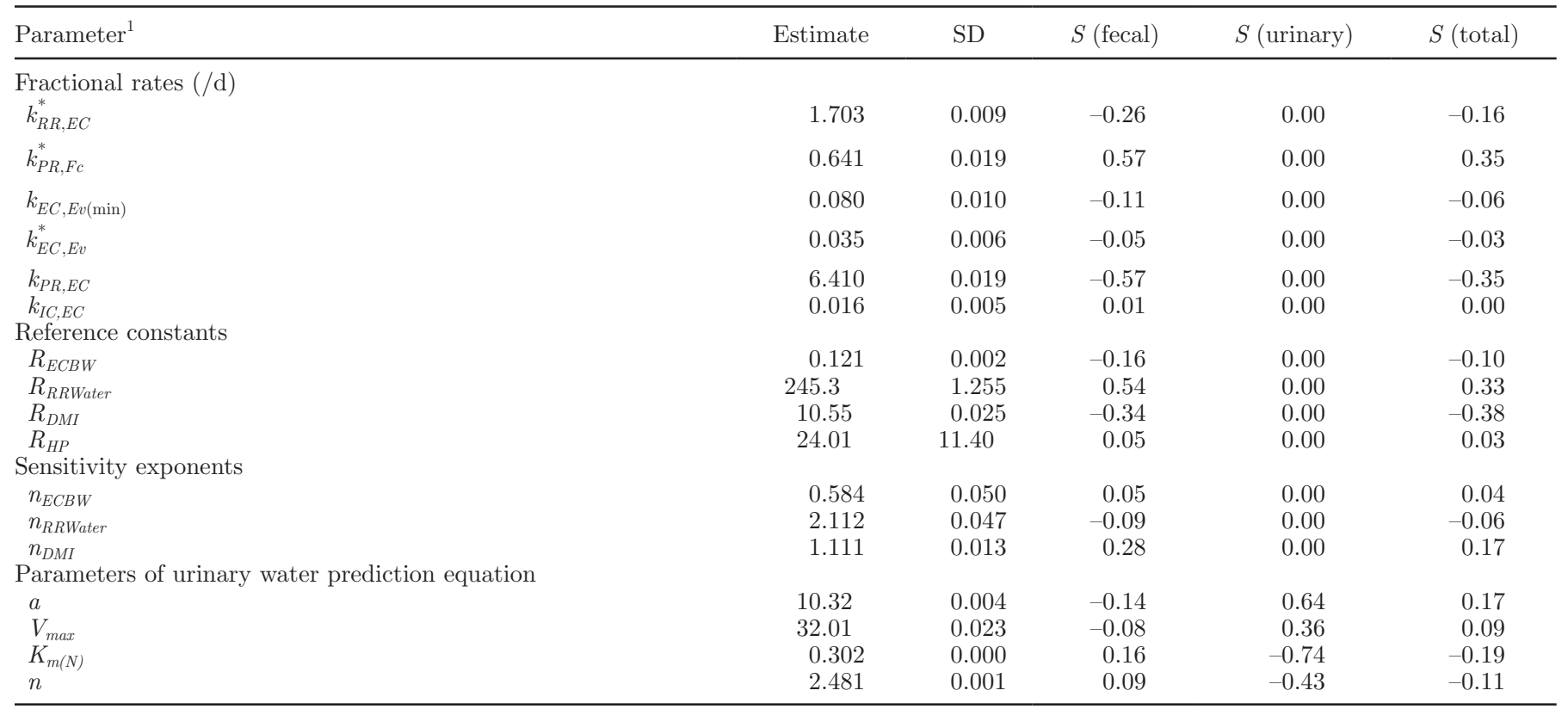

${ }^{1}$ See Table 3 and Table 4 for definition of mathematical notation and parameter abbreviations used in models. 


\section{RESULTS AND DISCUSSION}

A mechanistic, dynamic, and deterministic model was developed to determine daily urinary and fecal water excretions from lactating dairy cows. It also allowed estimation of drinking water intake, saliva output, and volumes and kinetics of gut and body water pools, absolute measures of which are challenging to obtain.

\section{Drinking Water Intake}

Dry matter intake, milk yield, dietary ash content, and dietary DM percentage were positively associated with drinking water intake (equation [9]). For each kilogram of DMI, cows consumed $2.75 \pm 0.20 \mathrm{~kg}$ of free water. This estimate is within the range of estimates $(2.38$ to $3.22 \mathrm{~kg} / \mathrm{kg}$ ) reported by Murphy et al. (1983), Holter and Urban (1992), and Khelil-Arfa et al. (2012). Independent of DMI, cows consumed an extra $0.84 \pm 0.08 \mathrm{~kg}$ of free water for each kilogram of milk they produced. This was also within the range of estimates $(0.60-0.92)$ reported by those authors. Dry matter intake and milk yield alone explained $75 \%$ of measured drinking water intake variability (data not shown). This is in agreement with Silanikove (1989), indicating that the food:water interrelationship is derived from a more basic relationship between digestible energy intake and water intake because DMI and milk yield explained $93 \%$ of digestible energy intake in the EMU database (data not shown). Additionally, a unit increase in dietary total ash content (\% of DM) and dietary DM percentage increased water intake by $2.32 \pm 0.54$ and $0.27 \pm 0.05 \mathrm{~kg} / \mathrm{d}$, respectively. The positive association between drinking water intake and dietary total ash content was not surprising given the previously demonstrated positive relationships between dietary sodium and free water intake (Cardot et al., 2008). The estimate of dietary DM percentage was less (0.27 vs. 0.62 and 0.83 ) than the estimates by Holter and Urban (1992) and Khelil-Arfa et al. (2012). Moreover, Khelil-Arfa et al. (2012) observed dietary DM percentage to be the strongest predictor of drinking water intake. Such an observation was not confirmed in the present study where DMI was the strongest predictor. Measured drinking water intake $(\mathrm{CV}=46 \%)$ and dietary DM percentage $(\mathrm{CV}=47 \%)$ were more variable in the data of Khelil-Arfa et al. (2012) than in the data used in the present study (CV $=36$ and $33 \%$, respectively). Perhaps the equation developed here did not capture the absolute relationship between water in feed and drinking water intake. However, the equation we developed was parameterized while accounting for random experiment and animal effects on drinking water intake. A mixed-model analysis should improve the extrapolating power of the equation (Bolker et al., 2009). Such adjustments were not applied in the construction of the equations (equations [36] and [37]) by Holter and Urban (1992) and Khelil-Arfa et al. (2012).

When evaluated against the data used to construct the equation (internal evaluation), drinking water predictions were closely related to measured values (Figure 3A). A similar relationship was seen when the equation was evaluated with data not used for model development as well. The associated RMSPE was 11.1 $\mathrm{kg} / \mathrm{d}$, which was $18.1 \%$ of average observed drinking water intake $(61.3 \mathrm{~kg} / \mathrm{d}$, Table 1). Moreover, absence of appreciable systematic errors indicates that the equation was properly parameterized. Among the other equations evaluated, that of Khelil-Arfa et al. (2012) (equation [37]) gave the best RMSPE of $24.0 \%$ of average observed value but was associated with notable slope bias. Prediction using the Murphy et al. (1983) equation (equation [35]) was associated with substantial mean bias. This was not surprising because the equation was developed primarily to predict water intake among early lactating Holstein cows. Nonetheless, better performance by the present equation could be due, in part, to the fact that data used for model development and evaluation were not completely independent because all the data were obtained in common experimental settings.

\section{Eating, Ruminating, and Saliva Production}

Dietary forage content and DMI had positive and negative effects, respectively, on chewing time (equations [1] and [2]). It is well established that chewing time increases as forage intake and forage particle length increase (Erdman, 1988). However, the particle length effect could not be tested due to the lack of data. Nonetheless, the negative association of DMI with $T_{E T}$ and $T_{R M}$ might partly account for the forage particle length effect, given the negative associations of forage particle length with DMI shown previously (Jaster and Murphy, 1983). Equation [1] predicted $T_{E T}$ with an RMSPE of $21.1 \%$ of the average observed value (13.3 $\mathrm{min} / \mathrm{kg}$ of DMI; Table 2). Moreover, $95 \%$ of the associated prediction error was random (Table 6). Equation [2] predicted $T_{R M}$ more successfully, as the RMSPE was just $10.5 \%$ of average observed value $(20.8 \mathrm{~min} /$ $\mathrm{kg}$ of DMI, Table 2), and $93.4 \%$ of the prediction error was due to random variability of data. With regard to the cows represented in the EMU database, the model estimated $T_{E T}$ ranging from 10 to 25 with a mean of $18 \mathrm{~min} / \mathrm{kg}$ DMI (Table 7). Corresponding estimates of $T_{R M}$ varied between 15 and 37 with a mean of 26 $\mathrm{min} / \mathrm{kg}$ of DMI. Analysis using 20 treatment means from 6 studies (Cassida and Stokes, 1986; Maekawa et 

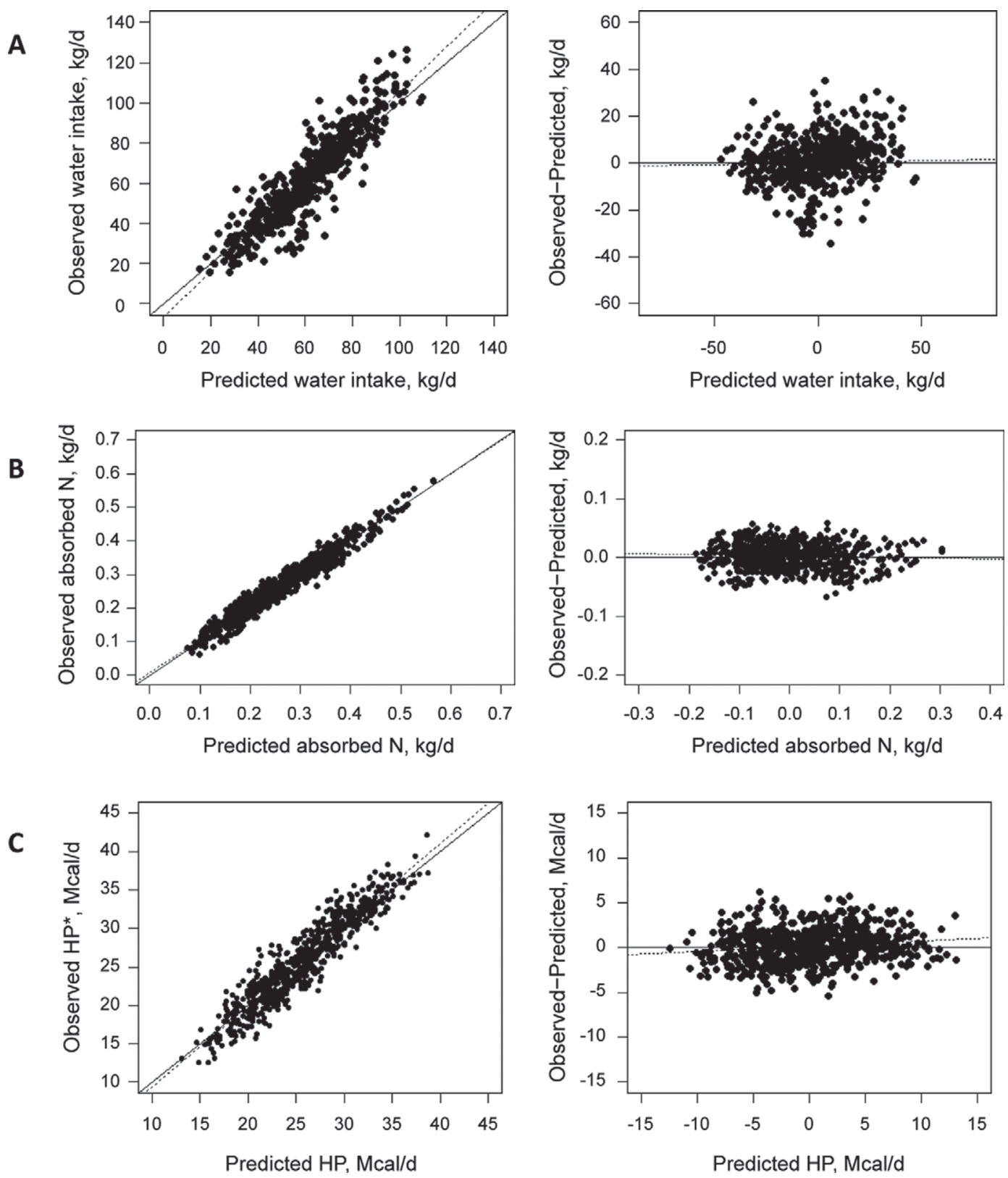

Figure 3. Relationships between observed versus predicted values and prediction error versus predicted values (centered on mean) for drinking water intake (A), absorbed N (B), and heat production (HP, C) of lactating Holstein cows ( $\mathrm{n}=670)$. Solid lines in respective plots indicate 1:1 unity between predicted and observed value and 0 prediction error. Dashed lines represent the relationships from simple linear regression models.

al., 2002; Beauchemin et al., 2003, 2008; Bowman et al., 2003; Mooney and Allen, 2007) showed that saliva secretion rates during eating $\left(S_{E T}\right)$ were significantly associated only with percentage of forage in the diet. For a unit increase in forage content, cows secreted $0.88 \pm 0.42 \mathrm{~g} / \mathrm{min}$ more saliva during eating (equation $[6])$. When compared with the literature values, $S_{E T}$ predictions from equation [6] were associated with a 9.6\% RMSPE (Table 6). The equation predicting saliva secretion rates during resting $\left(S_{R S}\right)$ was developed using 10 treatment means from 3 studies (Maekawa et al., 2002; Bowman et al., 2003; Mooney and Allen, 2007). Taking random study effect into account, high-producing cows were associated with greater saliva secretion rates during the resting period. For a unit increase in daily milk yield, cows secreted $3.86 \pm 0.24 \mathrm{~g} /$ min more saliva during resting (equation [7]). Predicted $S_{R S}$ had an RMSPE as percentage of average measured value 
Table 6. Model evaluation for drinking water intake $(\mathrm{kg} / \mathrm{d})$, eating time ( $T_{E T}, \min / \mathrm{kg}$ of DMI), ruminating time $\left(T_{R M}\right.$, min/ $\mathrm{kg}$ of DMI), saliva secretion rates $(\mathrm{kg} / \mathrm{min})$ during eating $\left(S_{E T}\right)$ and resting $\left(S_{R S}\right)$, fractional water passage from rumen $\left(k_{R R, P R}, / \mathrm{d}\right)$, absorbed $\mathrm{N}(\mathrm{kg} / \mathrm{d})$, heat production $(\mathrm{Mcal} / \mathrm{d})$, reticulorumen water mass $\left(Q_{R R}, \mathrm{~kg}\right)$, and fecal $\left(F_{P R, F_{C}}\right)$, urinary $\left(F_{E C, U r}\right)$, and total water excretion $(\mathrm{kg} / \mathrm{d})$

\begin{tabular}{|c|c|c|c|c|c|}
\hline Item & $\mathrm{RMSPE}^{1}$ & RMSPE\% & $\begin{array}{l}\text { Mean } \\
\text { bias }\end{array}$ & $\begin{array}{l}\text { Slope } \\
\text { bias }\end{array}$ & $\begin{array}{c}\text { Residual } \\
\text { bias }\end{array}$ \\
\hline \multicolumn{6}{|c|}{ Evaluation with data used for model development and optimization ${ }^{2}$} \\
\hline Drinking water intake & 10.3 & 16.2 & 1.1 & 4.7 & 94.2 \\
\hline$T_{E T}$ & 2.66 & 21.1 & 0.1 & 4.9 & 95.0 \\
\hline$T_{R M}$ & 2.08 & 10.5 & 4.8 & 1.8 & 93.4 \\
\hline \multicolumn{6}{|l|}{ Saliva secretion rates } \\
\hline Absorbed N & 0.002 & 7.3 & 0.5 & 0.1 & 99.4 \\
\hline Heat production & 1.93 & 7.5 & 0.8 & 2.2 & 97.0 \\
\hline$Q_{R R}$ & 11.7 & 16.3 & 31.2 & 19.4 & 49.3 \\
\hline \multicolumn{6}{|c|}{ Fecal and urinary water output } \\
\hline$F_{P R, F_{c}}$ & 3.67 & 14.3 & 0.0 & 0.1 & 99.9 \\
\hline$F_{E C, U r}$ & 4.75 & 29.1 & 0.3 & 0.1 & 99.6 \\
\hline Holter and Urban (1992) & 16.2 & 26.4 & 26.5 & 6.0 & 67.5 \\
\hline Khelil-Arfa et al. (2012) & 14.7 & 24.0 & 12.0 & 3.5 & 84.5 \\
\hline \multicolumn{6}{|c|}{ Fecal and urinary water output } \\
\hline$F_{P R, F c}$ & 4.05 & 15.6 & 0.7 & 1.9 & 97.4 \\
\hline$F_{E C, U r}$ & 4.93 & 30.6 & 2.2 & 0.6 & 97.2 \\
\hline Total water excretion & 6.11 & 14.6 & 0.4 & 1.5 & 98.4 \\
\hline
\end{tabular}

${ }^{1} \mathrm{RMSPE}=$ root mean square error of prediction.

${ }^{2}$ Data from indirect calorimetry experiments conducted in the USDA-Energy Metabolism Unit (EMU; Beltsville, MD) or from literature.

of $9.4 \%$. These estimates led to total saliva production estimates $\left(F_{S l, R R}\right)$ ranging from 102 to $317 \mathrm{~kg} / \mathrm{d}$, with a mean of $220 \mathrm{~kg} / \mathrm{d}$. On average, $14.1 \mathrm{~kg}$ of saliva was estimated to be produced per kilogram of DMI (Table 7). The daily total saliva production estimates (absolute and per $\mathrm{kg}$ of DMI) were in line with the means and ranges of measured values reported in the literature (e.g., Erdman, 1988).

\section{Fractional Rate of Water Passage from the Reticulorumen}

Equation [16] was used to determine the fractional rate of water passage from the reticulorumen $\left(k_{R R, P R}\right)$. When compared with literature values on which the equation was developed, $k_{R R, P R}$ predictions were associated with an RMSPE that was $17.9 \%$ of the average observed value (Table 6). Only DMI and dietary ADF content were significantly associated with $k_{R R, P R}$. For each unit increase in DMI and dietary ADF content, $k_{R R, P R}$ increased by 0.038 and $0.030 / \mathrm{d}$, respectively (equation [11]). The underlying mechanisms for these effects could be partly explained by reticulo-omasal orifice contractions playing a significant role in regulating liquid digesta passage from the rumen to the rest of the gut. Seo et al. (2007) demonstrated a positive association between DMI and reticulo-omasal orifice contraction frequency during eating. Okine et al. (1993) showed that the amplitude of reticulo-omasal orifice contractions may increase as dietary ADF content increases. The estimates of $k_{R R, P R}$ ranged between 0.09 and $0.14 / \mathrm{h}(2.13$ and $3.39 / \mathrm{d})$ with a mean of $0.12 / \mathrm{h}$ $(2.83 / \mathrm{d}$, Table 7$)$.

\section{Body Water Pools and Related Kinetics}

Although water inputs (drinking water, $F_{S l, R R}$, and $\left.F_{F d, R R}\right)$ and $k_{R R, P R}$ were determined using the equations discussed above, the model was fitted against measured fecal and urinary water output values and solved for the rest of the model parameters simultaneously. Estimates and sensitivity coefficients $(S)$ of the parameters are given in Table 5. Standard deviations (SD) of the parameter estimates, which were $<50 \%$ of the estimate in all cases, indicate that the data were adequate to parameterize the model. Besides the small SD, the notable sensitivity coefficients for the majority of model parameters, which were moderately correlated to each other (data not shown), indicated acceptable model parameter identifiability ( $\mathrm{Li}$ and $\mathrm{Vu}, 2013$ ). 
Table 7. Model estimates of key water balance variables pertaining to USDA-Energy Metabolism Unit (Beltsville, MD) database on lactating Holstein cows used for model development and optimization ${ }^{1}$

\begin{tabular}{|c|c|c|c|}
\hline Variable & Mean & Minimum & Maximum \\
\hline Drinking water, $\mathrm{kg} / \mathrm{d}$ & 61.5 & 22.8 & 104 \\
\hline$F_{F d, R R}, \mathrm{~kg} / \mathrm{d}$ & 10.6 & 1.11 & 31.3 \\
\hline$T_{E T}, \min / \mathrm{kg}$ of DMI & 18.0 & 10.0 & 25.0 \\
\hline$T_{R M}, \mathrm{~min} / \mathrm{kg}$ of DMI & 26.0 & 15.0 & 37.0 \\
\hline$S_{E T}, \mathrm{~kg} / \mathrm{min}$ & 0.22 & 0.18 & 0.26 \\
\hline$S_{R S}, \mathrm{~kg} / \mathrm{min}$ & 0.09 & 0.02 & 0.22 \\
\hline$F_{S I R R}, \mathrm{~kg} / \mathrm{d}$ & 220 & 102 & 317 \\
\hline$F_{S l, R R}: \mathrm{DMI}$ & 14.1 & 9.73 & 25.1 \\
\hline$T_{R R \text { Water }}$ & 283 & 126 & 433 \\
\hline$Q_{R R}, \mathrm{~kg}$ & 61.4 & 42.7 & 73.1 \\
\hline$Q_{P R}, \mathrm{~kg}$ & 24.4 & 14.6 & 30.2 \\
\hline$Q_{P R}: Q_{R R}$ & 0.40 & 0.33 & 0.50 \\
\hline Total gut water, $\mathrm{kg}$ & 85.8 & 57.3 & 103 \\
\hline Total gut water:BW & 0.14 & 0.08 & 0.24 \\
\hline$Q_{E C}, \mathrm{~kg}$ & 113 & 61.3 & 198 \\
\hline$Q_{E C}: \mathrm{BW}$ & 0.20 & 0.10 & 0.33 \\
\hline$Q_{I C}, \mathrm{~kg}$ & 197 & 139 & 261 \\
\hline$Q_{I C}: \mathrm{BW}$ & 0.33 & 0.24 & 0.42 \\
\hline$k_{R R, E C}, / \mathrm{d}$ & 1.74 & 0.76 & 3.04 \\
\hline$F_{R R, E C}, \mathrm{~kg} / \mathrm{d}$ & 108 & 37.4 & 192 \\
\hline$F_{P R, E C}, \mathrm{~kg} / \mathrm{d}$ & 159 & 117 & 184 \\
\hline$k_{R R, P R}, / \mathrm{d}$ & 2.83 & 2.30 & 3.21 \\
\hline$k_{P R, F c}, / \mathrm{d}$ & 1.02 & 0.47 & 1.65 \\
\hline$F_{P R, F c}, \mathrm{~kg} / \mathrm{d}$ & 25.7 & 6.04 & 50.0 \\
\hline$N_{A b}, \mathrm{~kg} / \mathrm{d}$ & 0.28 & 0.07 & 0.62 \\
\hline$N_{B}, \mathrm{~kg} / \mathrm{d}$ & 0.16 & 0.04 & 0.39 \\
\hline$H P$, Mcal/d & 25.6 & 14.9 & 37.7 \\
\hline$F_{M w, I C}, \mathrm{~kg} / \mathrm{d}$ & 3.15 & 1.83 & 4.64 \\
\hline$F_{E C, U r}, \mathrm{~kg} / \mathrm{d}$ & 16.6 & 10.6 & 31.2 \\
\hline$F_{E C, E v}, \mathrm{~kg} / \mathrm{d}$ & 13.1 & 6.11 & 29.8 \\
\hline
\end{tabular}

${ }^{1}$ See Table 3 for definition of mathematical notation and parameter abbreviations used in models.

Besides quantifying urinary and fecal water outputs, the model allows gut and body water pool masses to be estimated. Those estimates can then be used to calculate chemical (e.g., nutrient and metabolite) pool sizes of interest, given that the corresponding chemical concentrations are known from representative samples. Moreover, estimates of gut water volume are also important in calculating empty BW, which in turn can be used to determine body composition (Andrew et al., 1995). The $Q_{R R}$ estimates of cows used in the EMU experiments ranged from 42.7 to $73.1 \mathrm{~kg}$, with a mean of $61.4 \mathrm{~kg}$ (Table 7). Challenged with literature data on measured values (from rumen evacuation, $\mathrm{n}=81$ ), the model predicted $Q_{R R}$ with $16.3 \%$ RMSPE as a percentage of the average measured value (Table 6). Fractional rate of net water transfer via the reticulorumen wall $\left(k_{R R, E C}\right)$ was estimated to vary from $0.76 / \mathrm{d}(0.032 / \mathrm{h})$ to $3.04 / \mathrm{d}(0.127 / \mathrm{h})$ with a mean of $1.70 / \mathrm{d}(0.073 / \mathrm{h})$. This $k_{R R, E C}$ range is in line with measured values for sheep $(0.05-0.13 / \mathrm{h})$ reported by Willes et al. (1970). Estimated mean net water flow via the rumen wall $\left(F_{R R, E C}\right)$ was $108 \mathrm{~kg} / \mathrm{d}$ (Table 7). Seo et al. (2007) reported an average $F_{R R, E C}$ of $112 \mathrm{~kg} / \mathrm{d}$ for dairy cows, with a mean $Q_{R R}$ of $66 \mathrm{~kg}$. These estimates led to a $k_{R R, E C}$ of $1.70 / \mathrm{d}$, which is similar to the mean $k_{R R, E C}$ in the present study. Estimates of $Q_{P R}$ ranged from 14.6 to $30.2 \mathrm{~kg}$ with a mean of $24.4 \mathrm{~kg}$ (Table 7). The estimated ratio of $Q_{P R}: Q_{R}$ ranged between 0.33 and 0.50 with a mean of 0.40. Arnold and Trenkle (1986) and Andrew et al. (1995) reported ratios varying from 0.36 to 0.64 with a mean of 0.54 in Holstein cows and steers.

In the EMU indirect calorimetry experiments, $H P$ was estimated based on measurements of oxygen consumption, carbon dioxide and methane production, and urinary N excretion using the Brouwer (1965) equation (Reynolds and Tyrrell, 2000). These estimates were used to construct an equation for determining $H P$ in lactating dairy cows using more readily available data such as dietary nutrient composition, milk yield and milk composition, BW, DIM, and DMI. Predicted HP was in close agreement with the $H P$ estimates from indirect calorimetry experiments (Figure 3C), giving $7.5 \%$ RMSPE as a percentage of average value of the data (Table 6). Estimated HP was used to determine metabolic water production $\left(F_{M w, I C}\right.$, equation [33]) and fractional rate of RCW losses ( $k_{E C, E v}$, equation [29]). Estimates of $F_{M w, I C}$ ranged from 1.83 to $4.64 \mathrm{~kg} / \mathrm{d}$ with a mean of $3.15 \mathrm{~kg} / \mathrm{d}$. Expressed as a percentage of total water input (drinking water + water in feed $+F_{M w, I C}$ ), $F_{M w, I C}$ ranged from 3.04 to $8.35 \%$, which is close to the 


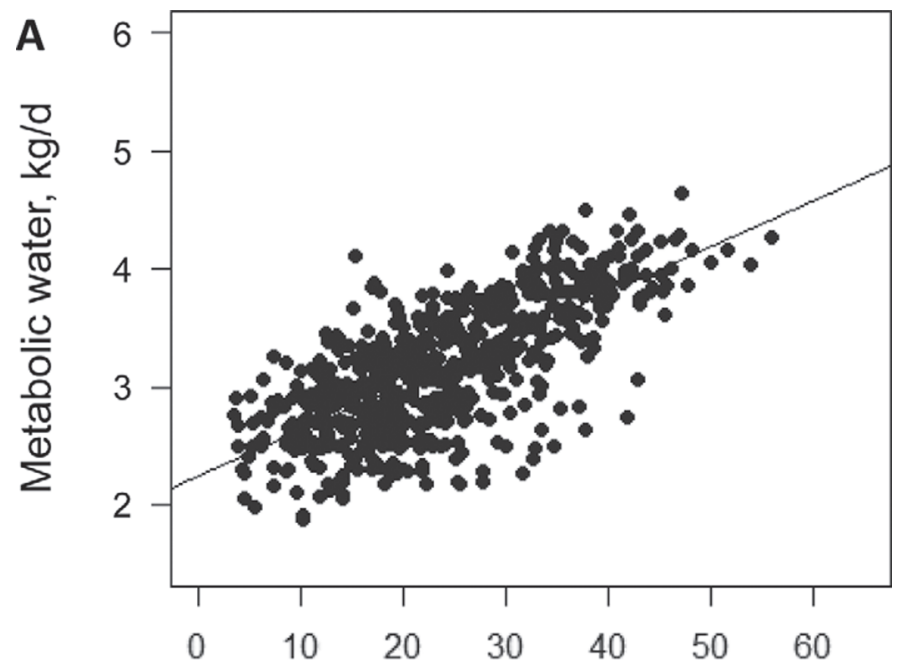

Milk yield, $\mathrm{kg} / \mathrm{d}$

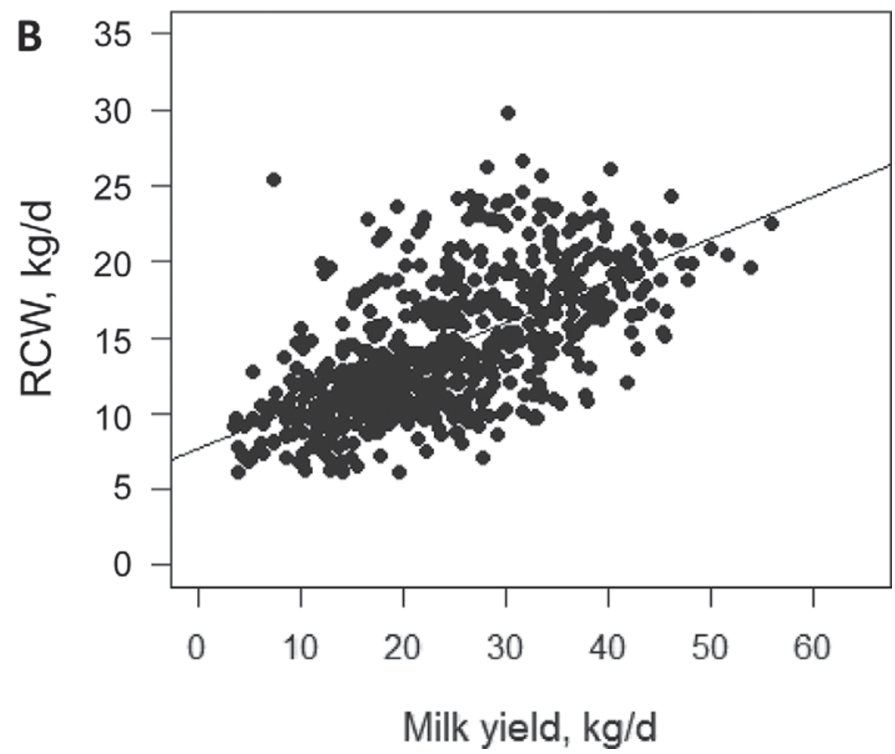

Figure 4. Relationships for metabolic water production (A) and respiratory-cutaneous water $(\mathrm{RCW}, \mathrm{B})$ losses with milk yield in lactating Holstein cows under thermoneutral conditions.

range of 5 to $10 \%$ reported by Beede (2012). Moreover, $F_{M w, I C}$ was positively associated $(P<0.001$; data not shown) with milk yield (Figure 4A).

Respiratory-cutaneous water losses can be separated into passive and thermoregulatory components. Thermoregulatory water loss is activated by panting and sweating. Animals kept under thermoregulatory conditions are basically associated with passive water loss, consisting only of respiratory loss plus cutaneous diffusion loss (Silanikove et al., 1997). Estimates of RCW loss $\left(F_{E C, E v}\right)$ ranged from 6.11 to $29.8 \mathrm{~kg} / \mathrm{d}$, with a mean of $13.1 \mathrm{~kg} / \mathrm{d}$. All of the calorimetry studies in the EMU database were conducted in a thermoneutral environment, with temperatures of about $25^{\circ} \mathrm{C}$ and relative humidity about $55 \%$. Each respiration chamber had an air conditioner and the entire building was air conditioned with temperature controls (William Flatt, Athens, GA; personal communication). Hence, the present model estimates (Table 7) are related to cows kept under thermoneutral conditions. Chew (1965) estimated, on average, $12.0 \mathrm{~kg} / \mathrm{d}$ passive RCW loss from a cow weighing $600 \mathrm{~kg}$. The mean estimate of $13.1 \mathrm{~kg} / \mathrm{d}$ $F_{E C, E v}$ for cows with average BW of $603 \mathrm{~kg}$ (Table 1) agrees closely with that of Chew (1965). Moreover, the estimated $F_{E C, E v}$ increased significantly $(P<0.001$; data not shown) as milk yield increased (Figure 4B). Consistently, lactating cows were found to be associated with greater RCW losses than dry cows (Holter and Urban, 1992; Silanikove et al., 1997). Under thermoneutral conditions, the lactating Holstein cows in Holter and Urban (1992) produced, on average, $35 \mathrm{~kg} / \mathrm{d}$ milk and appeared to be associated with a $F_{E C, E v}$ of 20 $\mathrm{kg} / \mathrm{d}$. The present model estimated an average $F_{E C, E v}$ of $18 \mathrm{~kg} / \mathrm{d}$ for cows yielding $35 \mathrm{~kg}$ of milk/d (Figure 4B).

When expressed as a fraction of $\mathrm{BW}, Q_{E C}$ and $Q_{I C}$ water mass estimates ranged between 0.10 and 0.33 , and 0.24 and 0.42 with means of 0.20 and 0.33 , respectively. Gad and Preston (1990) and Ross et al. (1992) determined mean $Q_{E C}$ and $Q_{I C}$ of cattle to be 21.5 and $32.3 \%$ of live BW, respectively. Net water transfer from the intracellular to extracellular compartment $\left(F_{I C, E C}\right.$, Figure 1) could be related to homeostatic control of volume and thereby osmolality of extracellular fluids, primarily blood plasma. As per the model parameter estimates (Table 5$)$, on average $1.6 \%\left(k_{I C, E C}=0.016 / \mathrm{d}\right)$ of $Q_{I C}$ was found to occur as a net transfer from $Q_{I C}$ to $Q_{E C}$ daily. Nonetheless, $k_{I C, E C}$ was associated with the smallest sensitivity coefficient (Table 5), suggesting that water output in fresh manure is nonresponsive to this net water transfer.

\section{Fecal and Urinary Water Excretion Predictions}

Fecal water contributes on average $61 \%$ of the total manure water output from lactating Holstein cows (Table 1). Internal evaluation of fecal water excretion predictions $\left(F_{P R, F c}\right)$ gave an RMSPE of $3.67 \mathrm{~kg} / \mathrm{d}$, which was $14.3 \%$ (Table 6) of the average observed value $(25.6 \mathrm{~kg} / \mathrm{d}$, Table 1$)$. We detected no tendency toward over- or under-prediction by the model (Figure 5A). In addition, residuals versus predicted values and error decomposition analyses (Table 6) showed no significant systematic bias, with $99.9 \%$ of the prediction error being due to random variation (Table 6). External evaluation gave an RMSPE of $4.05 \mathrm{~kg} / \mathrm{d}$ for 
A

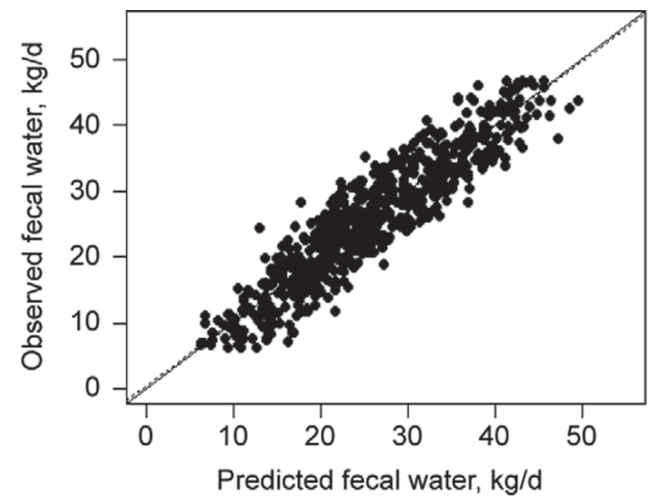

B

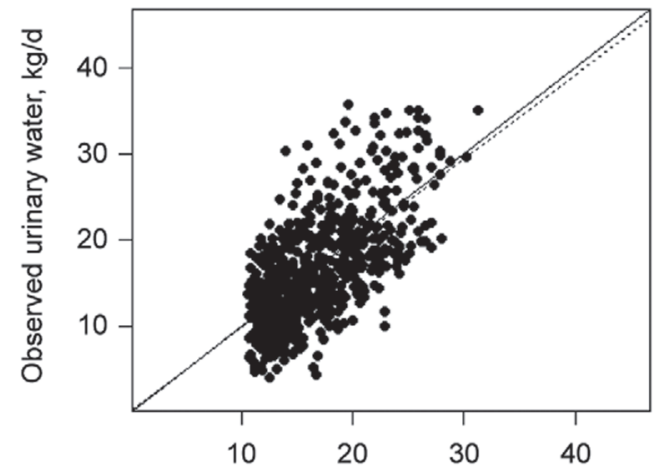

Predicted urinary water, $\mathrm{kg} / \mathrm{d}$

C

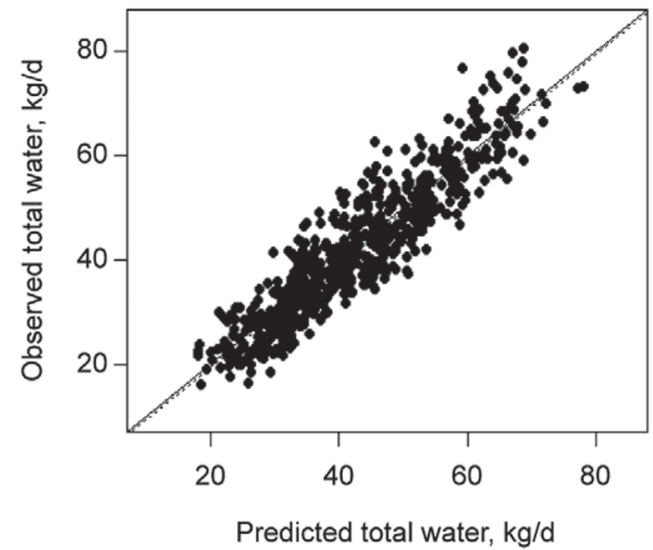

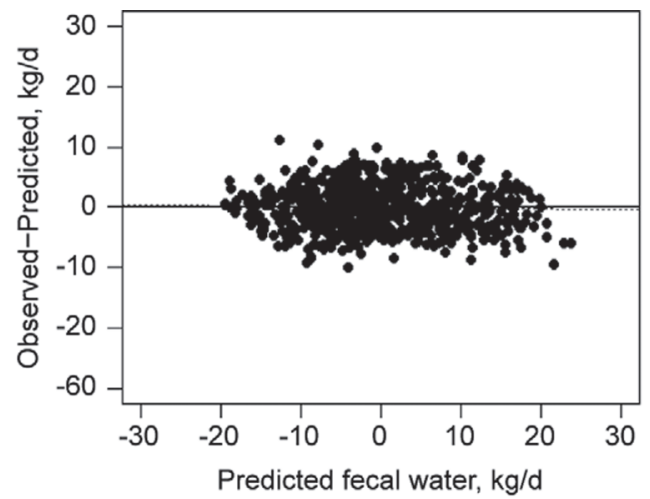

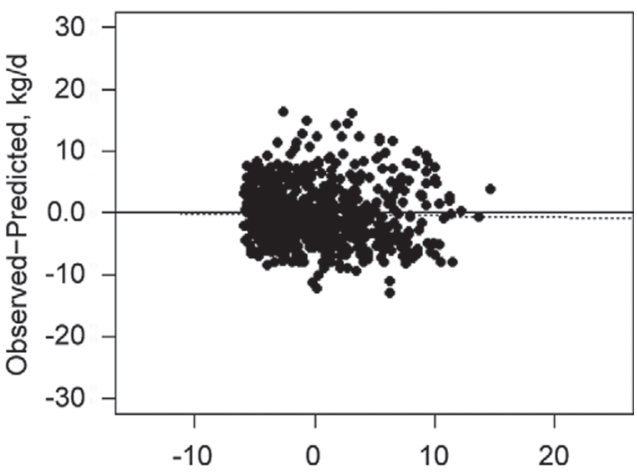

Predicted urine water, $\mathrm{kg} / \mathrm{d}$

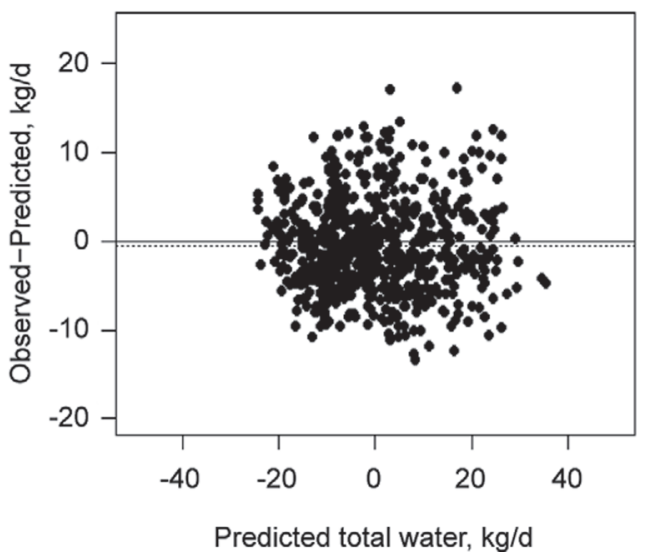

Figure 5. Relationships between observed versus predicted values and prediction error versus predicted values (centered on mean) for fecal (A), urinary (B), and total manure $(\mathrm{C})$ water output of lactating Holstein cows $(\mathrm{n}=670)$. Solid lines in respective plots indicate $1: 1$ unity between predicted and observed value and 0 prediction error. Dashed lines represent the relationships from simple linear regression models.

fecal water excretion, which was $15.6 \%$ of the average observed value (Table 1). The majority $(97.4 \%)$ of the error was nonsystematic, with only 0.7 and $1.9 \%$ of it due to mean bias and slope bias, respectively (Table 6).

Cattle produce urine with a fixed ceiling for urine osmolality (Maltz and Silanikove, 1996). If urea and mineral concentrations in the kidneys are high, more water is required for incorporation into urine because cattle cannot concentrate urine above that ceiling. Maltz and Silanikove (1996) observed a significant positive association between apparent digestible $\mathrm{N}\left(N_{A b}\right.$ in the present model) and urine output in high-yielding dairy cows. We observed a numerically stronger relationship of urine volume with $N_{A b}$ adjusted for $\mathrm{N}$ removed in milk $\left(N_{B}\right)$ than the relationship with just $N_{A b}(\mathrm{r}=0.60$ vs. 0.65 ; data not shown). Therefore, $N_{B}$ was chosen to model urinary water excretion rate $\left(F_{E C, U r}\right.$, equation [27]). The parameter estimates of the equation are given in Table 5 . Small SD ( $<2 \%$ of the estimates) imply that the data were adequate to describe the param- 
eters. Figure $6 \mathrm{~A}$ shows predicted and observed urinary water excretion rates $(\mathrm{kg} / \mathrm{d})$ plotted against $N_{B}$. When assessed visually (Figure $6 \mathrm{~A}$ ), predicted $F_{E C, U r}$ did not change greatly until $N_{B}$ increased to around $0.15 \mathrm{~kg} / \mathrm{d}$. At this point, the corresponding $F_{E C, U r}$ was a little less than $15 \mathrm{~kg} / \mathrm{d}$. The $N_{B}$ increasing above $0.15 \mathrm{~kg} / \mathrm{d}$ was associated with faster $F_{E C, U r}$ or excessive urine production, indicating cows were entering a diuretic phase. Consistently, Maltz and Silanikove (1996) reported that the upper limit for nondiuretic urine production of dairy cows was about $15 \mathrm{~kg} / \mathrm{d}$. The $0.15 \mathrm{~kg} / \mathrm{d} N_{B}$ was related to an $\mathrm{N}$ intake of about $0.40 \mathrm{~kg} / \mathrm{d}$ (Figure $6 \mathrm{~B}$ ). Given that the average $\mathrm{N}$ intake was 0.40 to $0.43 \mathrm{~kg} / \mathrm{d}$ (Table 1), a considerable number of cows in the EMU database appeared to be diuretic. Furthermore, Maltz and Silanikove (1996) pointed out that lactating dairy cows in nutritional experiments might be exposed to high renal osmotic loads. More successful representation of $F_{E C, U r}$ could have been made if $\mathrm{Na}$ and $\mathrm{K}$ intake and output data had been available. Such data allow calculation of total renal osmolality, which could be the greatest driver of urine volume. Absence of $\mathrm{Na}$ - and $\mathrm{K}$-specific effects on water intake and water excretion in lactating dairy cows is a limitation of the present model. Such effect representation would improve water excretion predictions over lactation because the relative contribution of urea and minerals to urine osmolality could vary over lactation (Shalit et al., 1991; Maltz and Silanikove, 1996). When evaluated with and without the data used for model construction, urinary water excretion predictions had an RMSPE of 4.75 and $4.93 \mathrm{~kg} / \mathrm{d}$, representing 29.1 and $30.6 \%$ of the average observed values, respectively. Again, in both cases, a significant proportion $(>97 \%)$ of the error was due to random variability of the data (Figure 5B, Table 6).

The present model predicted total fresh manure water output of lactating dairy cows with appreciable accuracy. When evaluated with data not used for model development and optimization, the RMSPE was $14.6 \%$ of the average observed value (Table 6). Again, a great majority of the error $(98.4 \%)$ was found to be due to random variability of the data. The notably low systematic error in all cases indicated that the corresponding mechanisms responsible for water balance in lactating dairy cows were appropriately represented and properly parameterized in the present model. Such success could be expected partly because the model was optimized for all parameters simultaneously using a relatively large number of observations.

A limitation of the model developed here is that it does not include temperature and humidity effects on water balance in lactating dairy cows. The data used for model development were from controlled calorimetric experiments in respiratory chambers that maintained thermoneutral conditions with a constant temperature of $25^{\circ} \mathrm{C}$ and a constant humidity level of $55 \%$. Therefore, satisfactory representation and parameterization of temperature effects could not be achieved, so model kinetics were represented assuming thermoneutral conditions. The model should be applied to lactating Holstein cows raised under thermoneutral conditions. On the other hand, the equations for saliva secretion (equations [1]-[8]) and fractional rate of water passage from the rumen (equation [16]) were constructed using data from published studies, some of which might not have been carried out under thermoneutral conditions. The model addresses variability in saliva secretion rates (equations [1] to [8]) using variables such as dietary forage percentage and milk production potential. However, more comprehensive mathematical representations ad-
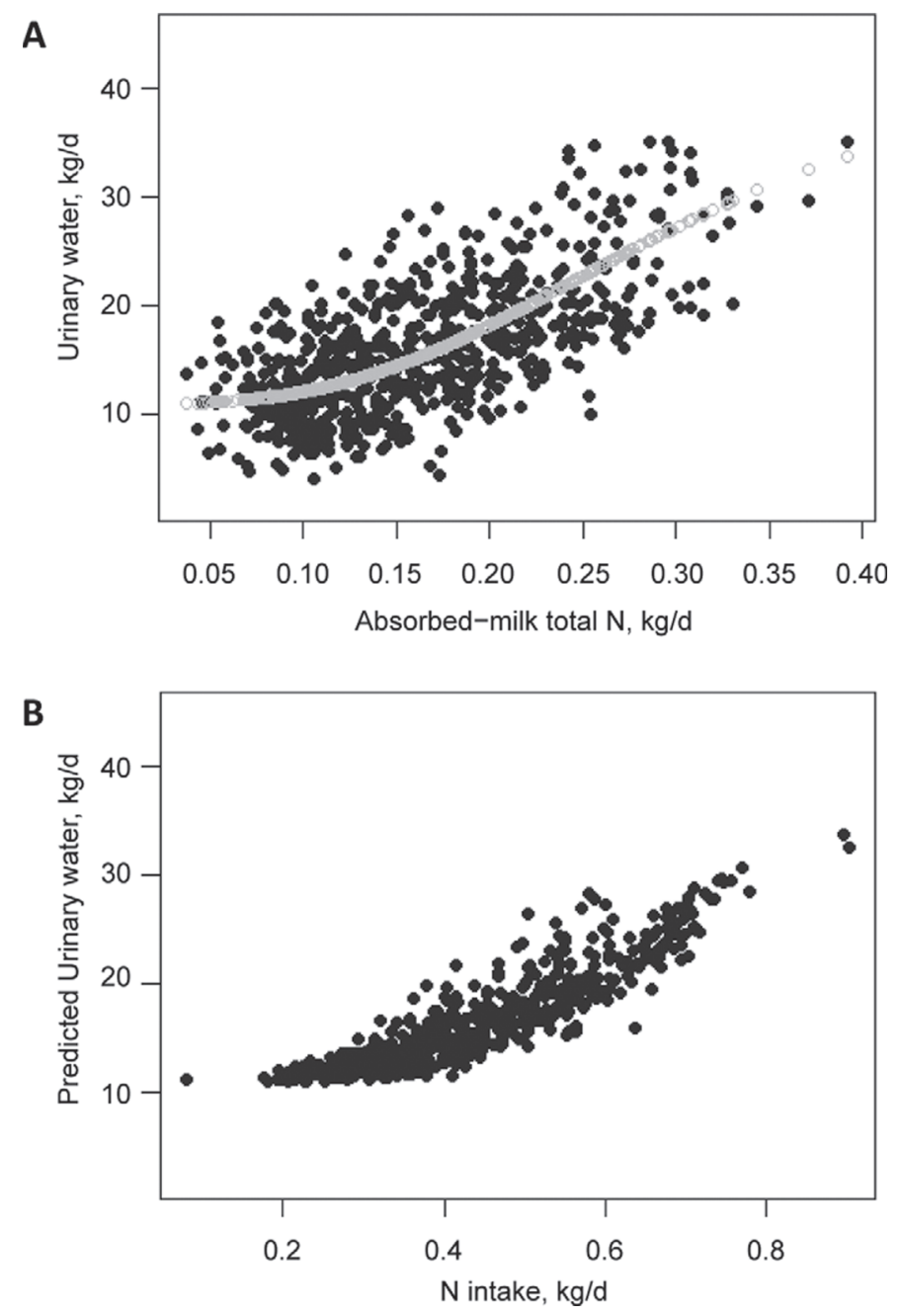

Figure 6. Observed urinary water output (black) and predicted urinary water output (gray) versus $\mathrm{N}$ balance between absorbed flow and flow into milk (A), and relationship between the predicted urinary water output and total $\mathrm{N}$ intake (B). 
dressing other relevant factors such as fluctuating blood osmolality would improve model predictions (Silanikove and Tadmore, 1989).

\section{CONCLUSIONS}

The mechanistic model developed herein predicted fresh manure water output from lactating Holstein cows under thermoneutral conditions well. The model predicted fecal water output with greater accuracy than it predicted urinary water output. The model could also be used to determine important body water pool volumes and related kinetics such as drinking water intake, saliva production, heat and metabolic water production, and respiratory cutaneous water losses. Absolute values of these fluxes are challenging to obtain. The model could be integrated within manure or soil dynamic models to assess water volumes that affect nutrient transformations.

\section{REFERENCES}

Agle, M., A. N. Hristov, S. Zaman, C. Schneider, P. Ndegwa, and V. K. Vaddella. 2010. The effects of ruminally degraded protein on rumen fermentation and ammonia losses from manure in dairy cows. J. Dairy Sci. 93:1625-1637.

Alamouti, A. A., M. Alikhani, G. R. Ghorbani, and Q. Zebeli. 2009 Effects of inclusion of neutral detergent soluble fibre sources in diets varying in forage particle size on feed intake, digestive processes, and performance of mid-lactation Holstein cows. Anim. Feed Sci. Technol. 154:9-23.

Andrew, S. M., R. A. Erdman, and D. R. Waldo. 1995. Prediction of body composition of dairy cows at three physiological stages from deuterium oxide and urea dilution. J. Dairy Sci. 78:1083-1095.

Anil, M. H., J. N. Mbanya, H. W. Symonds, and J. M. Forbes. 1993. Responses in the voluntary intake of hay or silage by lactating cows to intraruminal infusions of sodium acetate or sodium propionate, the tonicity of rumen fluid or rumen distension. Br. J. Nutr. 69:699-712.

Arnold, R. N., and A. Trenkle. 1986. Equilibration and passage of water in the gastrointestinal tract of cattle in relation to estimating body water by compartmental kinetic models. J. Anim. Sci. 63:1400-1409.

ASAE. 2005. Manure production and characteristics. ASAE Standard D384.2. American Society of Agricultural and Biological Engineers, St. Joseph, MI.

Bannink, A., H. Valk, and A. M. Van Vuuren. 1999. Intake and excretion of sodium, potassium, and nitrogen and the effects on urine production by lactating dairy cows. J. Dairy Sci. 82:1008-1018.

Beauchemin, K. A., L. Eriksen, P. Norgaard, and L. M. Rode. 2008 Short communication: Salivary secretion during meals in lactating dairy cattle. J. Dairy Sci. 91:2077-2081.

Beauchemin, K. A., and W. Z. Yang. 2005. Effects of physically effective fiber on intake, chewing activity, and ruminal acidosis for dairy cows fed diets based on corn silage. J. Dairy Sci. 88:2117-2129.

Beauchemin, K. A., W. Z. Yang, and L. M. Rode. 2003. Effects of particle size of alfalfa-based dairy cow diets on chewing activity, ruminal fermentation, and milk production. J. Dairy Sci. 86:630-643.

Beede, D. K. 2012. What will our ruminants drink? Anim. Front. 2:36-43.

Bibby, J., and H. Toutenburg. 1977. Prediction and Improved Estimation in Linear Models. John Wiley \& Sons, London, UK.
Bolker, B. M., M. E. Brooks, C. J. Clark, S. W. Geange, J. R. Poulsen, M. H. Stevens, and J. S. White. 2009. Generalized linear mixed models: A practical guide for ecology and evolution. Trends Ecol. Evol. 24:127-135.

Bowman, G. R., K. A. Beauchemin, and J. A. Shelford. 2002. The proportion of the diet to which fibrolytic enzymes are added affects nutrient digestion by lactating dairy cows. J. Dairy Sci. 85:3420-3429.

Bowman, G. R., K. A. Beauchemin, and J. A. Shelford. 2003. Fibrolytic enzymes and parity effects on feeding behavior, salivation and ruminal pH of lactating dairy cows. J. Dairy Sci. 86:565-575.

Brouwer, E. 1965. Report of sub-committee on constants and factors. Pages 441-443 in Energy Metabolism. Proc. 3rd Symp. K. L. Baxter, ed. Academic Press, London, UK.

Cafe, L. M., and D. P. Poppi. 1994. The fate and behaviour of imbibed water in the rumen of cattle. J. Agric. Sci. 122:139-144.

Canale, C. J., S. M. Abrams, L. D. Muller, W. L. Kjelgaard, P. M. Anderson, and H. W. Harpster. 1988. Alkali-treated forage for early lactation dairy cows: Effect on lactation performance and nutrient digestibility. J. Dairy Sci. 71:2166-2174.

Cardot, V., Y. Le Roux, and S. Jurjanz. 2008. Drinking behavior of lactating dairy cows and prediction of their water intake. J. Dairy Sci. 91:2257-2264.

Casper, D. P., H. A. Maiga, M. J. Brouk, and D. J. Schingoethe. 1999. Synchronization of carbohydrate and protein sources on fermentation and passage rates in dairy cows. J. Dairy Sci. 82:1779-1790.

Cassida, K. A., and M. R. Stokes. 1986. Eating and resting salivation in early lactation dairy cows. J. Dairy Sci. 69:1282-1292.

Chew, R. M. 1965. Water metabolism of mammals. Page 43 in Physiological Mammalogy. Vol. 2. W. W. Mayer, and R. G. van Gelder, ed. Acad. Press, New York, NY.

Couderc, J. J., D. H. Rearte, G. F. Schroeder, J. I. Ronchi, and F. J. Santini. 2006. Silage chop length and hay supplementation on milk yield, chewing activity, and ruminal digestion by dairy cows. J. Dairy Sci. 89:3599-3608.

Dado, R. G., and M. S. Allen. 1995. Intake limitations, feeding behavior, and rumen function of cows challenged with rumen fill from dietary fiber or inert bulk. J. Dairy Sci. 78:118-133.

Dennis, J. E., D. M. Gay, and R. E. Walsh. 1981. An adaptive nonlinear least-squares algorithm. ACM Trans. Math. Softw. 7:348-368.

Dijkstra, J., O. Oenema, J. W. van Groenigen, J. W. Spek, A. M. van Vuuren, and A. Bannink. 2013. Diet effects on urine composition of cattle and $\mathrm{N}_{2} \mathrm{O}$ emissions. Animal 7(Suppl. 2):292-302.

Erdman, R. A. 1988. Dietary buffering requirements of the lactating dairy cow: A review. J. Dairy Sci. 71:3246-3266.

Fernandez, I., C. Martin, M. Champion, and B. Michalet-Doreau. 2004. Effect of corn hybrid and chop length of whole-plant corn silage on digestion and intake by dairy cows. J. Dairy Sci. 87:1298-1309.

Fox, D. G., L. O. Tedeschi, T. P. Tylutki, J. B. Russell, M. E. Van Amburgh, L. E. Chase, A. N. Pell, and T. R. Overton. 2004. The Cornell Net Carbohydrate and Protein System model for evaluating herd nutrition and nutrient excretion. Anim. Feed Sci. Technol. 112:29-78.

Gad, S. M., and R. L. Preston. 1990. In vivo prediction of extracellular and intracellular water in cattle and sheep using thiocyanate and urea. J. Anim. Sci. 68:3649-3653.

Hill, A. V. 1910. The possible effects of the aggregation of the molecules of haemoglobin on its dissociation curves. J. Physiol. 40:4-6.

Holter, J. B., and W. E. Urban Jr. 1992. Water partitioning and intake prediction in dry and lactating Holstein cows. J. Dairy Sci 75:1472-1479.

Huhtanen, P., and U. Kukkonen. 1995. Comparison of methods, markers, sampling sites and models for estimating digesta passage kinetics in cattle fed at two levels of intake. Anim. Feed Sci. Technol. 52:141-158.

Jaster, E. H., and M. R. Murphy. 1983. Effects of varying particle size of forage on digestion and chewing behavior of dairy heifers. J Dairy Sci. 66:802-810.

Kammes, K. L., and M. S. Allen. 2012. Nutrient demand interacts with forage family to affect digestion responses in dairy cows. J. Dairy Sci. 95:3269-3287. 
Kammes, K. L., Y. Ying, and M. S. Allen. 2012a. Nutrient demand interacts with legume maturity to affect rumen pool sizes in dairy cows. J. Dairy Sci. 95:2632-2647.

Kammes, K. L., Y. Ying, and M. S. Allen. 2012b. Nutrient demand interacts with legume particle length to affect digestion responses and rumen pool sizes in dairy cows. J. Dairy Sci. 95:2616-2631.

Kargar, S., M. Khorvash, G. R. Ghorbani, M. Alikhani, and W. Z. Yang. 2010. Short communication: Effects of dietary fat supplements and forage:concentrate ratio on feed intake, feeding, and chewing behavior of Holstein dairy cows. J. Dairy Sci. 93:42974301.

Kendall, C., C. Leonardi, P. C. Hoffman, and D. K. Combs. 2009. Intake and milk production of cows fed diets that differed in dietary neutral detergent fiber and neutral detergent fiber digestibility. J. Dairy Sci. 92:313-323.

Khelil-Arfa, H., A. Boudon, G. Maxin, and P. Faverdin. 2012. Prediction of water intake and excretion flows in Holstein dairy cows under thermoneutral conditions. Animal 6:1662-1676.

Knowlton, K. F., V. A. Wilkerson, D. P. Casper, and D. R. Mertens. 2010. Manure nutrient excretion by Jersey and Holstein cows. J. Dairy Sci. 93:407-412.

Kononoff, P. J., and A. J. Heinrichs. 2003a. The effect of corn silage particle size and cottonseed hulls on cows in early lactation. J. Dairy Sci. 86:2438-2451.

Kononoff, P. J., and A. J. Heinrichs. 2003b. The effect of reducing alfalfa haylage particle size on cows in early lactation. J. Dairy Sci. 86:1445-1457.

Kononoff, P. J., A. J. Heinrichs, and H. A. Lehman. 2003. The effect of corn silage particle size on eating behavior, chewing activities, and rumen fermentation in lactating dairy cows. J. Dairy Sci. $86: 3343-3353$.

Krämer, M., P. Lund, and M. R. Weisbjerg. 2013. Rumen passage kinetics of forage- and concentrate-derived fiber in dairy cows. J. Dairy Sci. 96:3163-3176.

Krause, K. M., D. K. Combs, and K. A. Beauchemin. 2003. Effects of increasing levels of refined cornstarch in the diet of lactating dairy cows on performance and ruminal pH. J. Dairy Sci. 86:1341-1353.

Le Liboux, S., and J. L. Peyraud. 1998. Effect of forage particle size and intake level on fermentation patterns and sites and extent of digestion in dairy cows fed mixed diets. Anim. Feed Sci. Technol. 73:131-150.

Lechartier, C., and J. L. Peyraud. 2010. The effects of forage proportion and rapidly degradable dry matter from concentrate on ruminal digestion in dairy cows fed corn silage-based diets with fixed neutral detergent fiber and starch contents. J. Dairy Sci. 93:666-681.

Lechartier, C., and J. L. Peyraud. 2011. The effects of starch and rapidly degradable dry matter from concentrate on ruminal digestion in dairy cows fed corn silage-based diets with fixed forage proportion. J. Dairy Sci. 94:2440-2454.

Li, H., J. Qiu, L. Wang, and L. Yang. 2011. Advance in a terrestrial biogeochemical model-DNDC model. Acta Ecol. Sin. 31:91-96.

Li, P., and Q. D. Vu. 2013. Identification of parameter correlations for parameter estimation in dynamic biological models. BMC Syst. Biol. 7:91.

Lykos, T., G. A. Varga, and D. Casper. 1997. Varying degradation rates of total nonstructural carbohydrates: Effects on ruminal fermentation, blood metabolites, and milk production and composition in high producing Holstein cows. J. Dairy Sci. 80:3341-3355.

Maekawa, M., K. A. Beauchemin, and D. A. Christensen. 2002. Effect of concentrate level and feeding management on chewing activities, saliva production, and ruminal $\mathrm{pH}$ of lactating dairy cows. J. Dairy Sci. 85:1165-1175.

Maltz, E., and N. Silanikove. 1996. Kidney function and nitrogen balance of high-yielding dairy cows at the onset of lactation. J. Dairy Sci. 79:1621-1626.

Mathew, B., M. L. Eastridge, E. R. Oelker, J. L. Firkins, and S. K. Karnati. 2011. Interactions of monensin with dietary fat and carbohydrate components on ruminal fermentation and production responses by dairy cows. J. Dairy Sci. 94:396-409.
Maulfair, D. D., and A. J. Heinrichs. 2013a. Eating behavior, ruminal fermentation, and milk production in lactating dairy cows fed rations that varied in dry alfalfa hay and alfalfa silage content. Livest. Sci. 151:179-187.

Maulfair, D. D., and A. J. Heinrichs. 2013b. Effects of varying forage particle size and fermentable carbohydrates on feed sorting, ruminal fermentation, and milk and component yields of dairy cows. J. Dairy Sci. 96:3085-3097.

Maulfair, D. D., G. I. Zanton, M. Fustini, and A. J. Heinrichs. 2010. Effect of feed sorting on chewing behavior, production, and rumen fermentation in lactating dairy cows. J. Dairy Sci. 93:4791-4803.

McPhee, M., J. Oltjen, J. Fadel, D. Mayer, and R. Sainz. 2009. Parameter estimation and sensitivity analysis of fat deposition models in beef steers using acslXtreme. Math. Comput. Simul. 79:27012712 .

Mekonnen, M., and A. Hoekstra. 2012. A global assessment of the water footprint of farm animal products. Ecosystems (N. Y.) 15:401-415.

Michaelis, L., and M. L. Menten. 1913. Die Kinetik der Invertinwirkung. Biochem. Z. 49:333-369.

Mooney, C. S., and M. S. Allen. 2007. Effect of dietary strong ions on chewing activity and milk production in lactating dairy cows. J. Dairy Sci. 90:5610-5618.

Morrison, S. D. 1953. A method for the calculation of metabolic water. J. Physiol. 122:399-402.

Mowrey, A., M. R. Ellersieck, and J. N. Spain. 1999. Effect of fibrous by-products on production and ruminal fermentation in lactating dairy cows. J. Dairy Sci. 82:2709-2715.

Murphy, M. R., C. L. Davis, and G. C. McCoy. 1983. Factors affecting water consumption by Holstein cows in early lactation. J. Dairy Sci. $66: 35-38$

Nennich, T. D., J. H. Harrison, L. M. VanWieringen, N. R. St-Pierre, R. L. Kincaid, M. A. Wattiaux, D. L. Davidson, and E. Block 2006. Prediction and evaluation of urine and urinary nitrogen and mineral excretion from dairy cattle. J. Dairy Sci. 89:353-364.

Noftsger, S., N. R. St-Pierre, and J. T. Sylvester. 2005. Determination of rumen degradability and ruminal effects of three sources of methionine in lactating cows. J. Dairy Sci. 88:223-237.

Oba, M., and M. S. Allen. 2000. Effects of brown midrib 3 mutation in corn silage on productivity of dairy cows fed two concentrations of dietary neutral detergent fiber: 2. Chewing activities. J. Dairy Sci. 83:1342-1349.

Okine, E. K., A. Tesfaye, and G. W. Mathison. 1993. Relationships between reticular contractions and digesta passage in steers consuming alfalfa hay and barley straw combinations ad libitum. J. Anim. Sci. 71:3043-3051.

Rabelo, E., S. J. Bertics, J. Mackovic, and R. R. Grummer. 2001. Strategies for increasing energy density of dry cow diets. J. Dairy Sci. 84:2240-2249.

Reis, R. B., and D. K. Combs. 2000a. Effects of corn processing and supplemental hay on rumen environment and lactation performance of dairy cows grazing grass-legume pasture. J. Dairy Sci. 83:2529-2538.

Reis, R. B., and D. K. Combs. 2000b. Effects of increasing levels of grain supplementation on rumen environment and lactation performance of dairy cows grazing grass-legume pasture. J. Dairy Sci. 83:2888-2898.

Remond, D., F. Meschy, and R. Boivin. 1996. Metabolites, water and mineral exchanges across the rumen wall: Mechanisms and regulation. Ann. Zootech. 45:97-119.

Reynolds, C. K., and H. F. Tyrrell. 2000. Energy metabolism in lactating beef heifers. J. Anim. Sci. 78:2696-2705

Rius, A. G., S. Kittelmann, K. A. Macdonald, G. C. Waghorn, P. H. Janssen, and E. Sikkema. 2012. Nitrogen metabolism and rumen microbial enumeration in lactating cows with divergent residual feed intake fed high-digestibility pasture. J. Dairy Sci. 95:50245034 .

Ross, J. G., R. L. Preston, and S. J. Bartle. 1992. Evaluation of sodium thiosulfate as an extracellular water marker in cattle. J. Anim. Sci. 70:434-438. 
Sairanen, A., H. Khalili, J. I. Nousiainen, S. Ahvenjarvi, and P. Huhtanen. 2005. The effect of concentrate supplementation on nutrient flow to the omasum in dairy cows receiving freshly cut grass. J. Dairy Sci. 88:1443-1453.

San Emeterio, F., R. B. Reis, W. E. Campos, and L. D. Satter. 2000 Effect of coarse or fine grinding on utilization of dry or ensiled corn by lactating dairy cows. J. Dairy Sci. 83:2839-2848.

Seo, S., C. Lanzas, L. O. Tedeschi, and D. G. Fox. 2007. Development of a mechanistic model to represent the dynamics of liquid flow out of the rumen and to predict the rate of passage of liquid in dairy cattle. J. Dairy Sci. 90:840-855.

Shalit, U., E. Maltz, N. Silanikove, and A. Berman. 1991. Water, sodium, potassium, and chlorine metabolism of dairy cows at the onset of lactation in hot weather. J. Dairy Sci. 74:1874-1883.

Silanikove, N. 1989. Interrelationships between water, food and digestible energy intake in desert and temperate goats. Appetite 12:163-170.

Silanikove, N., E. Maltz, A. Halevi, and D. Shinder. 1997. Metabolism of water, sodium, potassium, and chlorine by high yielding dairy cows at the onset of lactation. J. Dairy Sci. 80:949-956.

Silanikove, N., and A. Tadmore. 1989. Rumen volume, saliva flow rate, and systemic fluid homeostasis in dehydrated cattle. Am. J. Physiol. 256:R809-R815.

Soltani, A., G. R. Ghorbani, M. Alikhani, A. Samie, and A. Nikkhah. 2009. Ground versus steam-rolled barley grain for lactating cows: A clarification into conventional beliefs. J. Dairy Sci. 92:3299-3305

Stensig, T., and P. H. Robinson. 1997. Digestion and passage kinetics of forage fiber in dairy cows as affected by fiber-free concentrate in the diet. J. Dairy Sci. 80:1339-1352.

Storm, A. C., and N. B. Kristensen. 2010. Effects of particle size and dry matter content of a total mixed ration on intraruminal equilibration and net portal flux of volatile fatty acids in lactating dairy cows. J. Dairy Sci. 93:4223-4238.

Storm, A. C., N. B. Kristensen, and M. D. Hanigan. 2012. A model of ruminal volatile fatty acid absorption kinetics and rumen epithelial blood flow in lactating Holstein cows. J. Dairy Sci. 95:2919-2934.
Teimouri Yansari, A., R. Valizadeh, A. Naserian, D. A. Christensen, P. Yu, and F. Eftekhari Shahroodi. 2004. Effects of alfalfa particle size and specific gravity on chewing activity, digestibility, and performance of Holstein dairy cows. J. Dairy Sci. 87:3912-3924.

Van Horn, H. H., A. C. Wilkie, W. J. Powers, and R. A. Nordstedt. 1994. Components of dairy manure management systems. J. Dairy Sci. 77:2008-2030.

Warner, A. C., and B. D. Stacy. 1972. Water, sodium and potassium movements across the rumen wall of sheep. Q. J. Exp. Physiol. Cogn. Med. Sci. 57:103-119.

Wilkerson, V. A., D. R. Mertens, and D. P. Casper. 1997. Prediction of excretion of manure and nitrogen by Holstein dairy cattle. J. Dairy Sci. 80:3193-3204.

Willes, R. F., V. E. Mendel, and A. R. Robblee. 1970. Water transfer from the reticulo-rumen in sheep. J. Anim. Sci. 31:85-91.

Winchester, C. F., and M. J. Morris. 1956. Water intake rates of cattle. J. Anim. Sci. 15:722-740.

Woodford, S. T., and M. R. Murphy. 1988. Dietary alteration of particle breakdown and passage from the rumen in lactating dairy cattle. J. Dairy Sci. 71:687-696.

Woodford, S. T., M. R. Murphy, and C. L. Davis. 1984. Water dynamics of dairy cattle as affected by initiation of lactation and feed intake. J. Dairy Sci. 67:2336-2343.

Yang, W. Z., and K. A. Beauchemin. 2006a. Effects of physically effective fiber on chewing activity and ruminal $\mathrm{pH}$ of dairy cows fed diets based on barley silage. J. Dairy Sci. 89:217-228.

Yang, W. Z., and K. A. Beauchemin. 2006b. Physically effective fiber: Method of determination and effects on chewing, ruminal acidosis, and digestion by dairy cows. J. Dairy Sci. 89:2618-2633.

Yang, W. Z., K. A. Beauchemin, and L. M. Rode. 2001. Barley processing, forage:concentrate, and forage length effects on chewing and digesta passage in lactating cows. J. Dairy Sci. 84:2709-2720.

Zebeli, Q., M. Tafaj, I. Weber, J. Dijkstra, H. Steingass, and W. Drochner. 2007. Effects of varying dietary forage particle size in two concentrate levels on chewing activity, ruminal mat characteristics, and passage in dairy cows. J. Dairy Sci. 90:1929-1942.

\section{APPENDIX}

Table A1. Equations contained in the model ${ }^{1,2}$

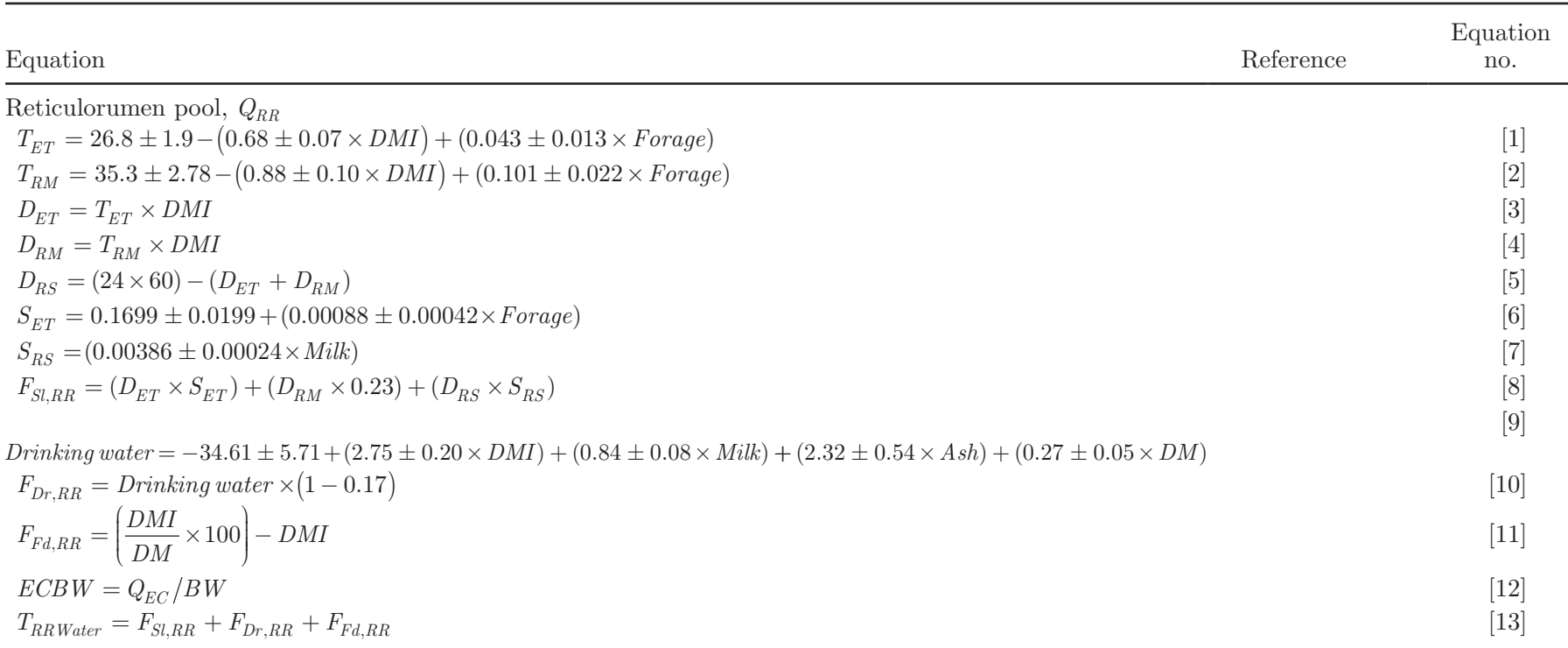


Table A1 (Continued). Equations contained in the model ${ }^{1,2}$

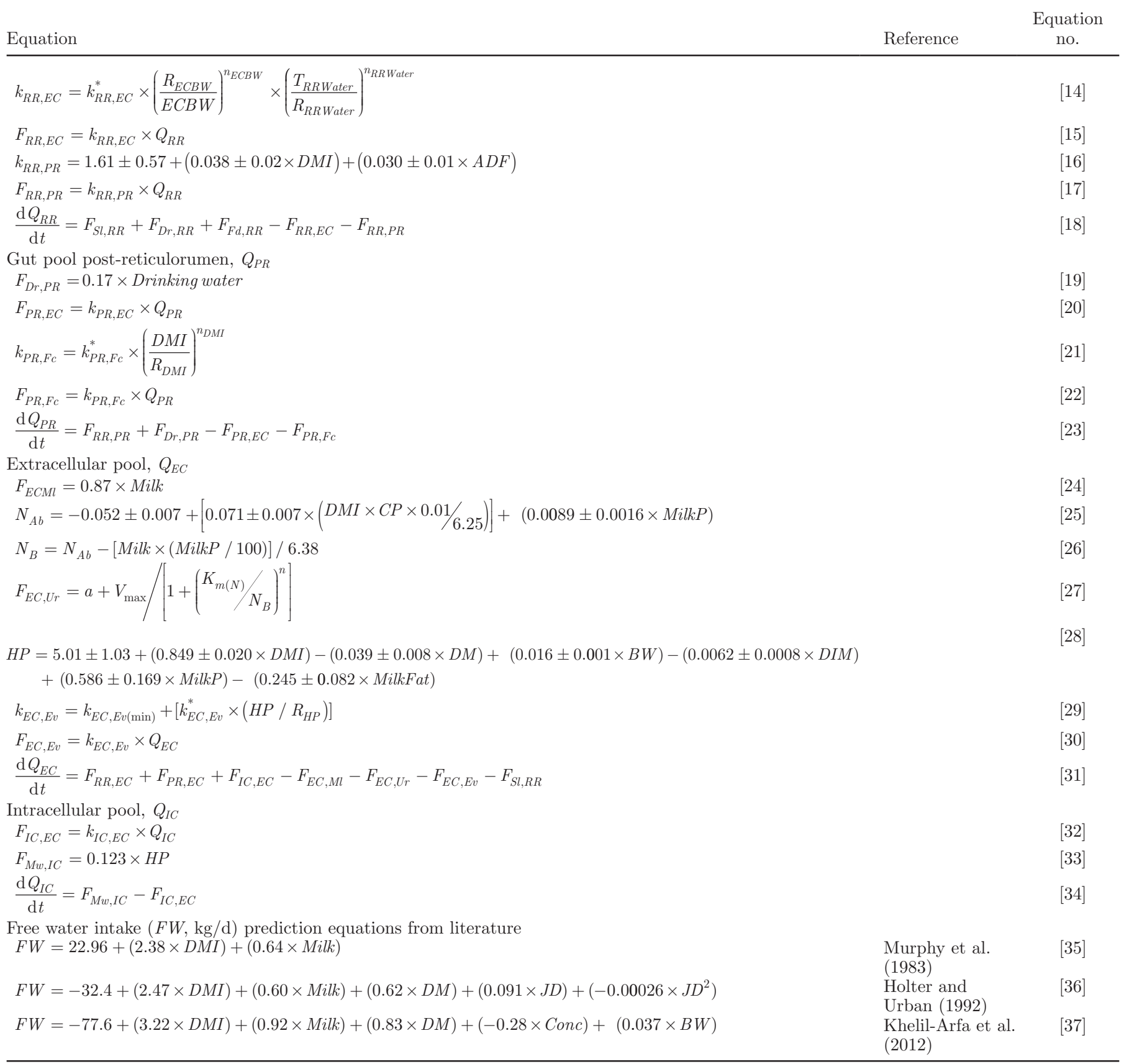

${ }^{1} D M I=$ dry matter intake $(\mathrm{kg} / \mathrm{d}), D M=$ dietary DM percentage, $A D F=$ dietary ADF percentage, $\mathrm{CP}=$ dietary $\mathrm{CP}$ percentage, $A$ sh $=$ dietary total ash percentage, Milk = milk yield $(\mathrm{kg} / \mathrm{d})$, MilkP = milk protein percentage, MilkFat = milk fat percentage, $B W=$ body weight $(\mathrm{kg})$, Forage $=$ forage percentage in the diet, $J D=$ Julian date (assumed to be constant at 200), Conc $=$ concentrate percentage in the diet.

${ }^{2}$ See Table 3 for definition of mathematical notation and parameter abbreviations used in models. 